\title{
Review of the Ordovician stratigraphy and fauna of the Anarak Region in Central Iran
}

ARTICLE in ACTA GEOLOGICA POLONICA · JANUARY 2015

ImpactFactor: 0.84- DOI: 10.1515/apg-2015-0022

READS

26

6 AUTHORS, INCLUDING:

National Museum Wales

231 PUBLICATIONS 2,239 CITATIONS

SEE PROFILE

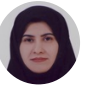

Mansoureh Ghobadi Pour

Golestan University

69 PUBLICATIONS 365 CITATIONS

SEE PROFILE
Vachik Hairapetian

Islamic Azad University Khorasgan (Isfahan) Branch

33 PUBLICATIONS 130 CITATIONS

SEE PROFILE

Lars E Holmer

Uppsala University

211 PUBLICATIONS 2,319 CITATIONS

SEE PROFILE 


\title{
Review of the Ordovician stratigraphy and fauna of the Anarak Region in Central Iran
}

\author{
LEONID E. POPOV ${ }^{1}$, VACHIK HAIRAPETIAN ${ }^{2}$, DAVID H. EVANS 3 , \\ MANSOUREH GHOBADI POUR ${ }^{4}$, LARS E. HOLMER ${ }^{5}$ and CHRISTIAN BAARS ${ }^{1}$ \\ ${ }^{1}$ Department of Geology, National Museum of Wales, Cardiff CF10 3NP, Wales, United Kingdom. \\ E-mail:leonid.popov@museumwales.ac.uk,christian.baars@museumwales.ac.uk \\ ${ }^{2}$ Department of Geology, Isfahan (Khorasgan) Branch, Islamic Azad University, \\ PO Box 81595-158, Isfahan, Iran. \\ E-mail:vachik@khuisf.ac.ir \\ ${ }^{3}$ Natural England, Suite D, Unex House, Bourges Boulevard, Peterborough PE1 1NG, England, \\ United Kingdom.E-mail: david.evans@naturalengland.org.uk \\ ${ }^{4}$ Department of Geology, Faculty of Sciences, Golestan University, Gorgan, Iran. \\ E-mail:mghobadipour@yahoo.co.uk \\ ${ }_{5}^{5}$ Institute of Earth Sciences, Palaeobiology, Uppsala University, SE-752 36 Uppsala, Sweden. \\ E-mail:Lars.Holmer@pal.uu.se
}

\begin{abstract}
:
Popov, L.E., Hairapetian, V., Evans, D.H., Ghobadi Pour, M., Holmer, L.E. and Baars, C. 2015. Review of the Ordovician stratigraphy and fauna of the Anarak Region in Central Iran. Acta Geologica Polonica, 65 (4), 403-435. Warszawa.

The Ordovician sedimentary succession of the Pol-e Khavand area, situated on the northern margin of the Yazd block, has important differences from those in other parts of Central Iran. It has been established that the presumably terminal Cambrian to Lower Ordovician volcano-sedimentary Polekhavand Formation, exposed in the Pol-e Khavand area, has non-conformable contact with greenschists of the Doshakh Metamorphic Complex. The succeeding, mainly siliciclastic Chahgonbad Formation contains low to moderately diverse faunal assemblages, including brachiopods, cephalopods, trilobites and tentaculitids. The Darriwilian age of the lower part of the formation is well established by the co-occurrence of brachiopod genera Camerella, Phragmorthis, Tritoechia and Yangtzeella. The associated rich cephalopod fauna is different from the Darriwilian cephalopod associations of the Alborz terrane and may show some affinity with warm water faunas of North China and South Korea. It is likely that the Mid Ordovician fauna recovered from the lower part of the Chahgonbad Formation settled in the area sometime during a warming episode in the late Darriwilian. By contrast the low diversity mid Katian brachiopod association includes only three taxa, which occur together with the trilobite Vietnamia cf. teichmulleri and abundant, but poorly preserved tentaculitids questionably assigned to the genus Costatulites. This faunal association bears clear signatures linking it to the contemporaneous cold water faunas of the Arabian, Mediterranean and North African segments of Gondwana. Four brachiopod species recovered from the Chahgonbad Formation, including Hibernodonta lakhensis, Hindella prima, Lomatorthis? multilamellosa and Yangtzeella chupananica are new to science.
\end{abstract}

Key words: Darriwilian; Katian; Brachiopods; Cephalopods; Trilobites; Biogeography. 


\section{INTRODUCTION}

Fossiliferous Ordovician deposits in the Pol-e Khavand area, south-east of the town of Anarak, in the north-eastern part of the Esfahan Province are known mainly from the final report on geological mapping of the area by Sharkovski et al. (1984), who reported the occurrence of brachiopods, cephalopods, trilobites, echinoderms and some other fossils sampled at several horizons within the Ordovician succession, which was assigned to the Shirgesht Formation. None of this material has been the subject of subsequent taxonomical study. In 2004 a team of Italian geologists revisited the area to sample biostratigraphically constrained sites for palaeomagnetic studies. In the course of their fieldwork, they collected three samples containing abundant ostracod assemblages described subsequently by Schallreuter et al. (2006). In recent years the Early Palaeozoic sedimentary succession in the vicinity of Anarak has been the subject of extensive studies by a joint team of researchers from Azad University, Esfahan, the Gulestan University, Gorgan, the National Museum of Wales, Cardiff and Uppsala University. This work has resulted in the development of new lithostratigraphical subdivisions for the area (Hairapetian et al. 2015). The non-conformable contact between the Doshakh Metamorphic Complex and the overlying Lower Palaeozoic deposits first reported by Sharkovskii et al. (1984) has also been confirmed (Hairapetian et al. 2015). This is of potential importance for re-evaluating existing models of the tectonic evolution of Central Iran through the Palaeozoic. The major objective of the present study is to document and assess the palaeobiogeographical affinities of the Mid to Late Ordovician faunas sampled in the Pol-e Khavand area during these studies.

Material illustrated and/or discussed below is deposited in the National Museum of Wales (NMW) under accession numbers NMW2012.7G (brachiopods, trilobites and tentaculitids) and NMW2014.6G (cephalopods).

\section{GEOLOGICAL OUTLINE}

The Pol-e Khavand area is situated on the northern margin of the Yazd block, in the north-western part of the Central-East Iranian Microplate (Text-fig. 1). The presence of the Ordovician deposits in the area was revealed for the first time by Russian geologists during geological mapping for 1:100.000 sheets of the Geological Survey of Iran (Sharkovskii et al. 1984). In developing a lithostratigraphical subdivision of the
Lower Palaeozoic part of the sedimentary succession, they applied the formal units earlier established by Ruttner et al. (1968) for the adjacent Tabas Block, eastern Central Iran. Consequently the Ordovician portion of the sedimentary succession of the Pol-e Khavand area was assigned to the Shirgesht Formation (Sharkovski et al. 1984).

As recently demonstrated by Hairapetian et al. (2015), the early Palaeozoic sedimentary succession in the Pol-e Khavand area differs significantly from that described by Ruttner et al. (1968) for the Derenjal Mountains. As a consequence, new lithostratigraphical subdivisions have been proposed for the Ordovician deposits developed in the area. The presumably ?Cambrian (Furongian) to Lower Ordovician interval has been assigned to the volcano-sedimentary Polekhavand Formation, which rests non-conformably on greenschists of the Doshakh Metamorphic Complex. In the absence of diagnostic fossils, the age of the Polekhavand Formation has been inferred from its position between the Doshakh metamorphites and the newly introduced Chahgonbad Formation, which contains a distinct Darriwilian faunal assemblage at its base.

The Middle to Upper Ordovician Chahgonbad Formation is separated by a disconformity from the underlying Polekhavand Formation. This unit is the only source of fossils documented in the present study. The sampled section is situated about $21 \mathrm{~km}$ south-east of the town of Anarak. It is located in the Pol-e Khavand area at about $1.5-2 \mathrm{~km}$ south-west of the eastern foothills of the Pol-e Khavand Mountains (Text-fig. 1). Geographical coordinates of the measured section zero point are $33^{\circ} 10^{\prime} 50^{\prime \prime} \mathrm{N}$; E $53^{\circ} 53^{\prime} 40^{\prime \prime} \mathrm{E}$, at an elevation of $1384 \mathrm{~m}$. The total thickness of the succession is about $505 \mathrm{~m}$. It is situated in the same area where the Russian mapping team made a stratigraphical log of the unmetamorphosed Lower Palaeozoic deposits (Sharkovski et al. 1984). The Chahgonbad Formation is separated by a paraconformity from the Silurian (Rhuddanian to Aeronian) transgressive black shales (so-called 'hot shales'), which are at present not assigned to any formal lithostratigraphical unit.

The Chahgonbad Formation can be subdivided into six informal units (Hairapertian et al. 2015) (see Text-fig. 2) as follows:

Unit C1. Oligomict microconglomerates and coarse-grained sandstones, total up to $10.5 \mathrm{~m}$.

Unit C2. Brownish-purple, argillaceous bioclastic limestones with a bed of oolitic ironstone up to $0.4 \mathrm{~m}$ thick at the base, total $8.7 \mathrm{~m}$ thick.

Unit C3. Grey argillites and sandstones with several tuff horizons, total up to $115 \mathrm{~m}$ thick. 


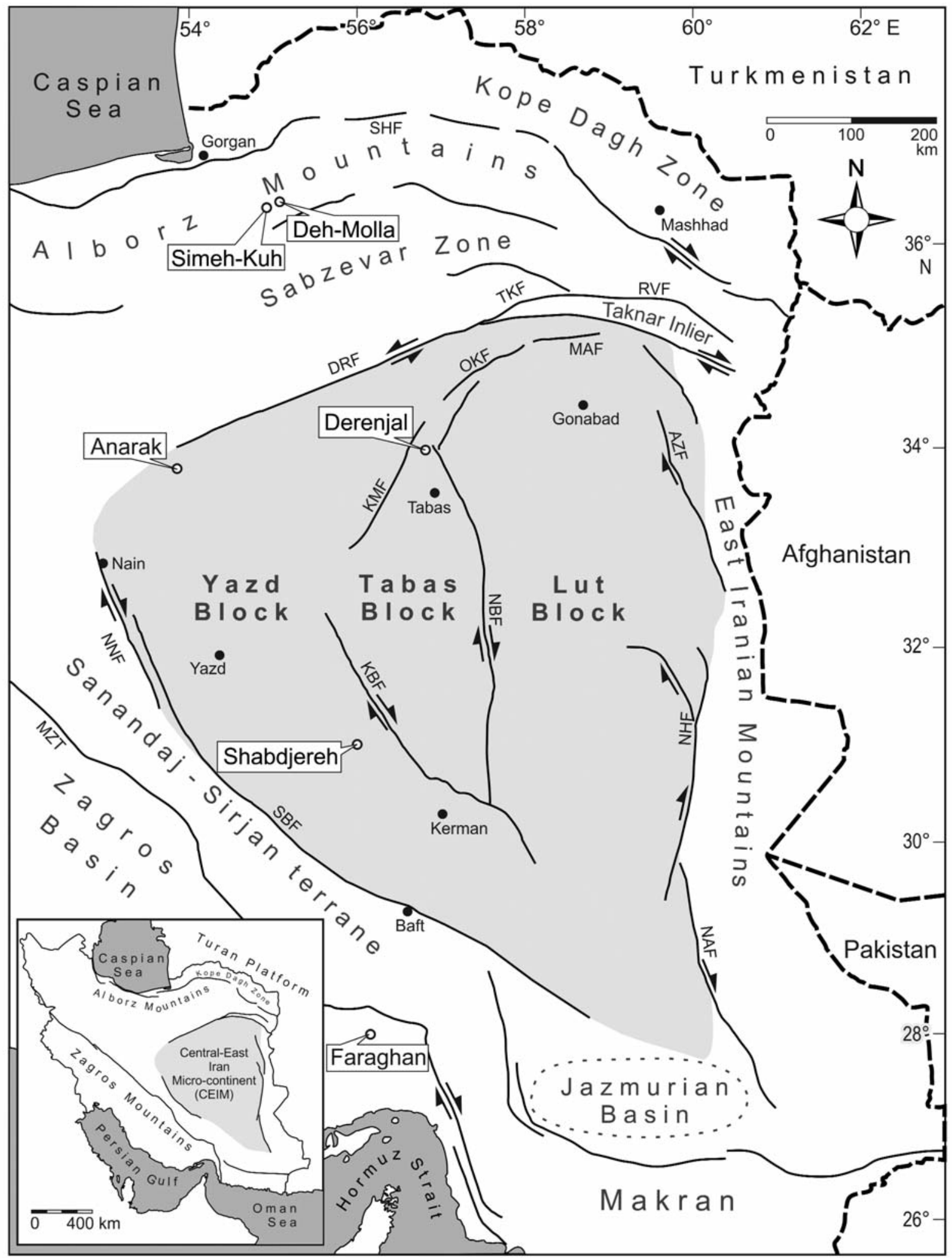

Text-fig. 1. Simplified structural maps of Iran showing position of Ordovician fossil localities discussed in the paper (mainly after Ramezani and Tucker 2003 and Hairapetian et al. 2012), with modifications; structural data compiled from various sources, e.g., Berberian and King (1981), Lindenberg et al. (1984) and Alavi (1991). Abbreviations: AZF - Abiz fault; DRF - Doruneh fault; KBF - Kuhbanan fault; KMF - Kalmard fault; MAF - Mehdiabad fault; MZT - Main Zagros thrust; NAF - Nostratabad fault; NBF - Nay band fault; NHF - Nehbandan fault; NNF - Nain fault; OKF - Ozbak Kuh fault; RVF - Rivash fault; SBF - Shahre-Babak fault; SHF - Syahkuh fault; TKF - Taknar fault 


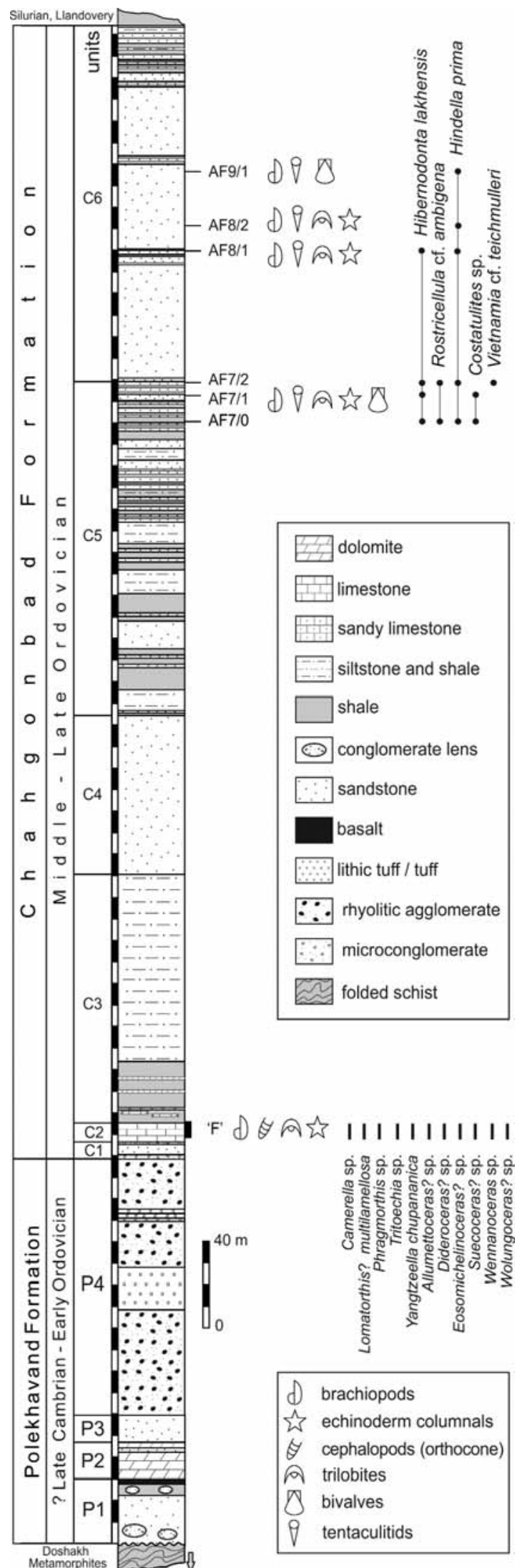

Unit C4. Violet-red sandstones with a few beds of argillites and siltstones, cross-bedded sandstones in the upper $15 \mathrm{~m}$, total $73.6 \mathrm{~m}$ thick.

Unit C5. Violet-red and greenish red argillites, siltstones and sandstones up to $136 \mathrm{~m}$ thick.

Unit C6. Violet-red and greenish-red sandstones with siltstone and argillite intercalations in the middle and upper part, total $161 \mathrm{~m}$ thick.

Unit C2 is the equivalent of the lower part of ' Unit 6' of the stratigraphical log of Sharkovski et al. (1984), and of 'Unit F' of the description of the fossiliferous part of the succession given by Schallreuter et al. (2006). Three samples, which were the source of the diverse ostracod assemblages described by Schallreuter et al. (2006, fig. 2) were derived from the lower $4 \mathrm{~m}$ of the unit. In addition to ostracods, this interval (Text-fig. 2, sample F; Text-fig. 3) contains a moderately diverse assemblage that includes the brachiopods Camerella sp., Lomatorthis? multilamellosa sp. nov., Phragmorthis sp., Tritoechia sp. Yangtzeella chupananica sp. nov.; the cephalopods Allumettoceras? sp., Dideroceras? sp., Eosomichelinoceras? sp., Suecoceras? sp., Wennanoceras sp. and Wolungoceras? sp., and poorly preserved trilobites represented by indeterminate Asaphidae.

The next fossiliferous horizons (Text-fig. 2; samples AF-7/0, AF-7/1, AF-7/2) are from the upper part from Unit C5. Unit C3 and Unit C4 are barren. A low diversity faunal assemblage recovered from Unit C5 includes the brachiopods Hindella prima sp. nov., $\mathrm{Hi}$ bernodonta lakhensis sp. nov. and Rostricellula cf. ambigena Havliček, 1961, the trilobite Vietnamia cf. teichmulleri (Hamman and Leone 1997) and the tentaculitid Costatulites sp. The next unit (Unit C6) also contains three fossiliferous horizons (Text-figs 2, 4, samples AF-8/1, AF-8/2 and 9/1). The lowermost of these (sample AF-8/1) contains just two brachiopod species, Hindella prima and Hibernodonta lakhensis. The two upper horizons contain a monotaxic association of Hindella prima.

The overlying Silurian black shales are strongly weathered, although they are overlain by siliciclastic and carbonate sediments with a characteristic Aeronian fauna, that includes the diagnostic brachiopods species Stegocornu procerum Dürkoop, 1970, Stegocornu denisae Popov et al., in Hairapetian et al. 2012, and Pentamerus asiaticus Cocks, 1979, typical of the Iranian post-extinction recovery fauna (Hairapetian et al. 2012; Popov et al. 2014).

Text-fig. 2. Stratigraphical column of the Ordovician deposits exposed in the Pol-e Khavand area, showing lithostratigraphical subdivision, position of sampled fossiliferous horizons and stratigraphical distribution of brachiopods, cephalopods, trilobites and tentaculitids 


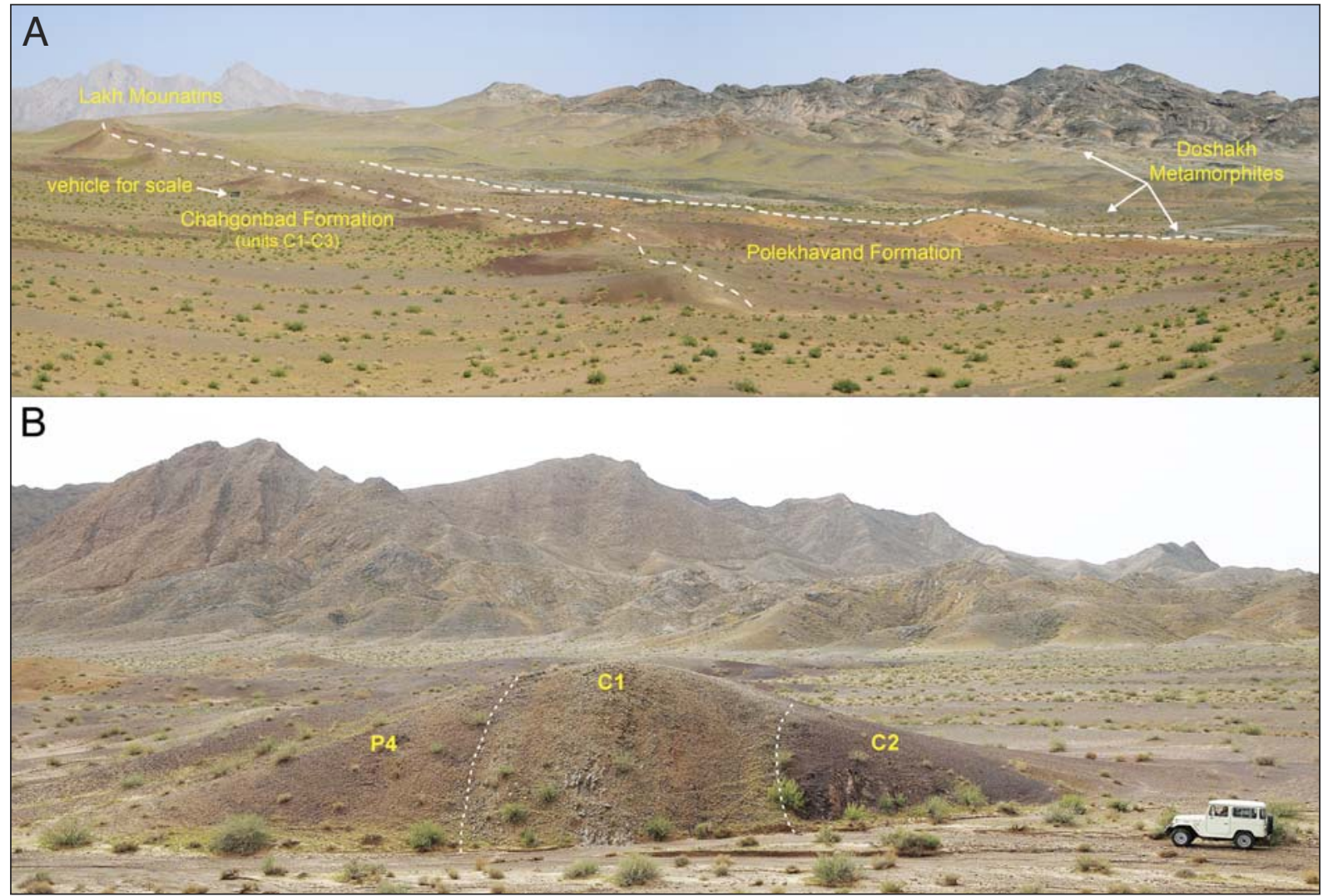

Text-fig. 3. A - General northwestwardly view of the outcrop showing Doshahk metamorphics, the Polekhavand Formation and the lower part of the Chahgonbad Formation. B - Lithostratigraphic units of P4 (Polekhavand Formation), C1 and C2 (Chahgonbad Formation) showing position of sample 'F'. This is the same outcrop as the site IR12 of Schallreuter et al. (2006, fig. 3B)

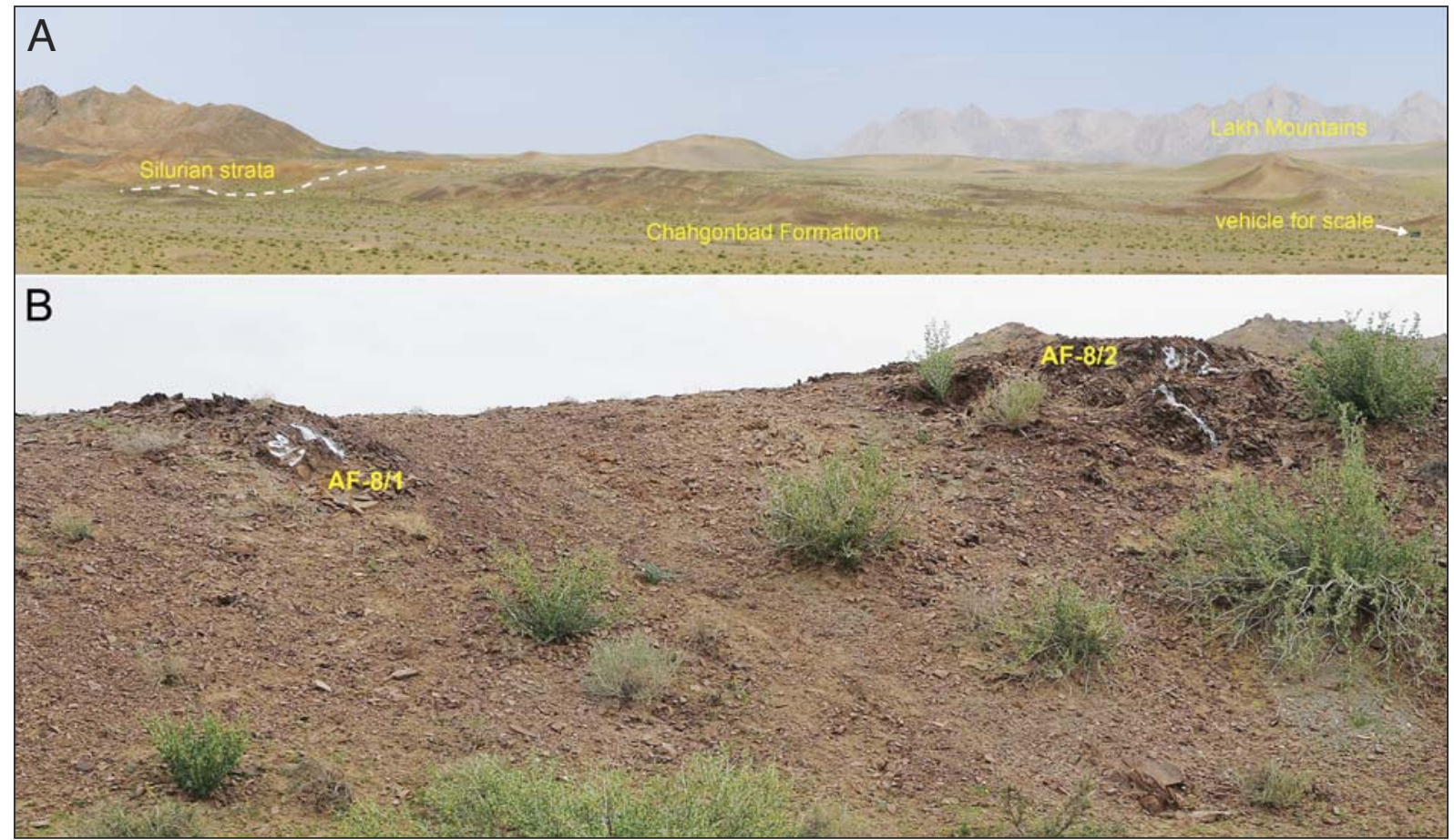

Text-fig. 4. A - General westwardly view of the Chahgonbad Formation. B - General view of the outcrop showing the middle part of Unit C6 and location of samples AF- $8 / 1$ and AF- $8 / 2$ in the upper part of the Chahgonbad Formation 


\section{PRESERVATION}

\section{Brachiopods, trilobites and tentaculitids}

Brachiopods are the most common fossils of Unit $\mathrm{C} 2$. They are mostly preserved as disarticulated and exfoliated shells, and unlike the ostracods they are not silicified. Highly argillaceous carbonate rocks of the unit permitted to dissolve the shell to make artificial external and internal moulds with the subsequent preparation of silicon casts that are helpful for precise taxonomic identification; in particular, taxa such as Tritoechia and Yangtzeella. Specimens from C5 and C6 are preserved entirely as external and internal moulds in a relatively coarse, sandy matrix, and therefore faint morphological features, such as the ornament on the shell surface, denticulation on the teeth and sockets in strophomenides, as well as the cardinalia in small rhynchonellide shells are usually obscured and difficult to observe. Tentaculitides are preserved exclusively as external moulds, and therefore the morphology of the chambers inside the conch is impossible to observe.

\section{Cephalopods}

The cephalopods consist of about twenty-five specimens that mostly represent portions of phragmocone, many of which are quite fragmentary, and most are heavily corroded externally. This hampers taxonomic determination, which for much of the material described below is markedly reliant on the internal morphology of the specimens.

Most specimens are entirely invested with sediment, but the presence of sparite lining and filling the camerae of some individuals indicates that parts of the phragmocone may have remained relatively intact after the death of the organism, whilst the presence of sediment fill in the core of many of the sparite filled camerae suggests that the conchs may have remained on or just below the sea floor for some time prior to final burial (e.g. NMW2014.6G.1, 16). The sediment infilling the phragmocone appear to consist of micrite or a micritic mudstone. Coarser material may also be present and may be concentrated into particular camerae (e.g. NMW2014.6G.5) or in the vicinity of the phragmocone wall (e.g. NMW2014.6G.15). This material consists of shell debris, of which only echinoderm ossicles are a recognisable component. In some specimens (e.g. NMW2014.6G.5), the matrix is mottled in a way that suggests that it was caused by bioturbation. Often, the boundaries between the coarser grains and the matrix are indistinct, possibly as a consequence of recrystallisation or the development of neomorphic textures.
In corroded cross-sections such as that seen in NMW2014.6G.2 and 16, the trace of the endocones stand out in relief, but they cannot be detected in a cut and polished section. This again suggests that neomorphic textures may be developed. In addition, the edges of the septa and connecting rings, as with the coarser components of the matrix, may be diffuse, or the whole structure may only remain only as 'ghosts' (NMW2014.6G.12). A number of specimens (NMW2014.6G.2, 4, 10) exhibit a dark, specular material within the matrix and endosiphuncular deposits, which, since this appears to be present in both materials, is likely to be a diagenetic product, and may be associated with the partial replacement of septa, connecting rings, cameral and endosiphuncular deposits with (on the grounds of their strong red and ochreous colouration) a complex of iron oxides, hydroxides and carbonate.

Some specimens (e.g. NMW2014.6G.10) are deformed and sheared. They exhibit the alignment of fabrics including clasts as well as textures considered to be of a late diagenetic origin.

Given the preservational history of these specimens, and the complex diagenesis that has contributed to obscuring diagnostic features, no attempt has been made to assign individuals to species or new taxa. For the same reason, most of the generic assignments have to be treated with a degree of uncertainty.

The small quantity of material available for study, consisting of 25 individuals is insufficient for rarefaction analysis and assessment of the taxonomic completeness of the assemblage. Nevertheless, the application of the software package 'Analytical Rarefaction 1.4' by S.M. Holland to this sample (Text-fig. 5) suggests that the sample may be substantially incomplete; as is also suggested by the small number of individuals $($ maximum $=3$ ) representing each of the taxa described below.

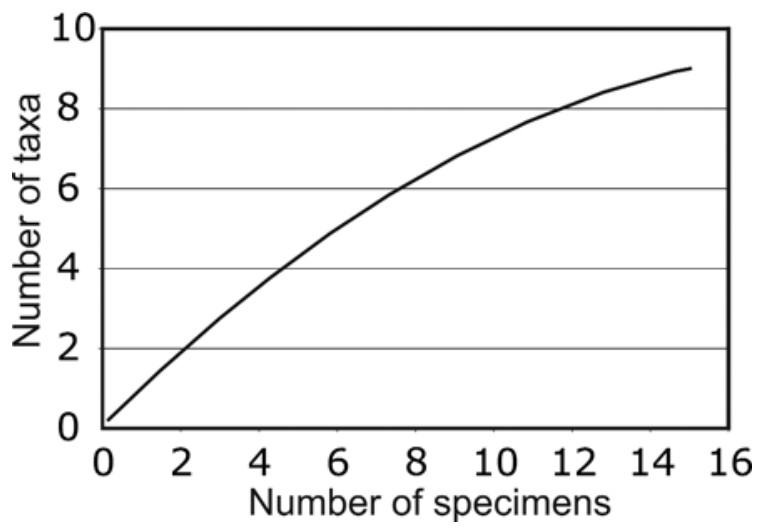

Text-fig. 5. Rarefaction plot of the cephalopod assemblage. This indicates that the fauna may be more diverse than currently recognised. The sample size may, however, be too small to provide confidence of the result of the analysi 


\section{STRATIGRAPHICAL AND PALAEOBIOGEO- GRAPHICAL RELATIONSHIPS}

\section{Brachiopods}

The Mid to Late Ordovician faunas recovered from the Chahgonbad Formation were previously unknown from Central Iran. A brachiopod fauna from the Katkoyeh Formation of the Kerman Region (Shabdjereh section, Text-fig. 1), documented by Percival et al. (2009) and dated as the early Darriwilian (Lenodus variabilis Conodont Biozone), contains Leptellina, Martellia and Paralenorthis. None of these genera are present in the brachiopod assemblage recovered from the Chahgonbad Formation. A Darriwilian brachiopod fauna is also documented from the Simeh-Kuh and Deh-Molla localities in Alborz Region (Ghobadi Pour et al. 2011). This fauna is considered by Ghobadipour (2006) and Popov (2009) as a part of a separate Peri-Gondwana microplate that remained unattached to the Gondwana margin through the Early Palaeozoic. The Darriwilian fauna of the Alborz Region shows high turnover rates. The early to mid Darriwilian brachiopod associations of Alborz are of low diversity and they contain large proportion of endemic genera. Co-occurrence with trilobites characteristic of Neseuretus biofacies suggests a substantial cooling at that time. The late Darriwilian is characterised in Alborz be invasion of the Saucrorthis Brachiopod Fauna, which is unknown elsewhere in Iran, but is widespread in South China through the Darriwilian (Zhan et. al. 2007, 2014) and probably settled in Alborz sometime in the late Darriwilian as the climate became warmer.

The brachiopod association from the Unit C2 includes two biostratigraphically informative taxa, Tritoechia and Yangtzeella, which first appear respectively in the Tremadocian and the Floian, both with upper ranges extending into the Darriwilian, although neither genera extends into the Upper Ordovocian (Popov et al. 2001; Rong et al. 2005; Zhan and Jin 2005a; Ghobadi Pour et al. 2011). Camerella and Phragmorthis first appear in the Darriwilian (Ross 1972; Popov et al. 2005; Zhan and Jin 2005a). The overlap of the stratigraphical distributions of these four genera occurs in the Darriwilian. The Darriwilian age of Unit C2 is therefore considered well established here, contradicting the Late Ordovician date assigned to the same unit by Schallreuter et al. (2006). The occurrence of Yangtzeella, which is for the first time reported from Central Iran, is a good indication of the east peri-Gondwana affinities of the assemblage. The genus is otherwise known from South China (Rong et al. 2005a, 2005b), the Alborz terrane
(Ghobadi Pour et al. 2011), Turkish Taurides (Cocks and Fortey 1988), and the Chu-Ili Terrane of Kazakhstan (Nikitina et al. 2006). Camerella and Phragmorthis are a common element of low latitude faunas, suggesting that faunal association under study settled in the area sometime during the late Darriwilian warming episode. This is further supported by the affinity of some elements of the associated cephalopod assemblage to the low latitude faunas of North China and South Korea as it is discussed in more details later in this paper. Increased northwardly directed migration of the trilobite taxa along the west Gondwana margin in the late Darriwilian has been discussed also by Ghobadi Pour and Popov (2009). At that time Central Iran was situated within the 'overlap zone' (see also Fortey and Cocks 2003), and might represent a major gate-way for faunal migrations.

A low diversity brachiopod fauna from units C5 and C6 contains only three taxa. Two of them are new species currently regarded as endemic to the area, while Rostricellula cf. ambigena Havliček, 1961 is a wellknown species, which is relatively common in the lower Katian of the Mediterranean segment of Gondwana. This species has a relatively long stratigraphical range (Time Slices from Sa1 to Ka2), and occurs in strata ranging from the Vinice to Bohdalec formations of the Prague Basin in Bohemia (Havlíček and Vanek 1966). It is also reported by Villas (1985) from Spain, while in Anti-Atlas, Morocco, Rostricellula ambigena occurs in the uppermost Lower Ktaoua and upper Tiouririne formations (Colmenar and Álvaro 2014). The athyridide Hindella is confined to the upper Katian and ranges up into the Llandivery (Sheehan 1977). The overlap between these two taxa may occur in the uppermost part of Time Slice Ka2 (the lower part of the Pleurograptus linearis Graptolite Biozone and the upper part of the Acanthochitina barbata Chitinozoan Biozone equivalent). Hindella prima sp. nov. is potentially the earliest representative of the genus. The associated faunal assemblage include taxa which are otherwise confined to the Mediterranean, North African and Arabian segments of Gondwana (Rostricellula cf. ambigena, Vietnamia cf. teichmulleri (Hamman and Leone 1997) and can be considered to represent a cold water fauna.

The earliest, late Sandbian to early Katian athyridides were documented from the Kazakh terranes, which were located at that time in the tropics in relative proximity to the Australasian Segment of Gondwana (Bassett et al. 1999; Popov et al. 1999). By mid Katian time they spread along the western margin of Gondwana and arrived at the 'overlap zone' (Bassett et al. 1999) where Hindella originally evolved as a component of the cold-water brachiopod associations. 


\section{Cephalopods}

The affinities of the cephalopod faunas from the Darriwilian portions of the Shirgesht Formation in Central Iran and the Lashkarak Formations of the eastern Alborz Mountains were considered to be with Baltica and South China (Evans et al. 2013). It was also recognised that this fauna was likely to have affinities with those of northern Gondwana (e. g. Armorica and Perunica), once those faunas are better known. Similar affinities with Baltica and South China were observed in an assemblage noted by Bogolepova et al. (2013) from the Abastu Formation of Abarsaj, Semnan. Whilst the presence of Dideroceras and Suecoceras in the Chahgonbad Formation may also indicate such affinities, other elements of the assemblage may indicate links with North China. Wolungoceras foesteri from the Floian Wolung Limestone of Liaoning, northeast China is clearly older than the specimen described below. Whilst Wolungoceras remains poorly known, it is difficult to place any substantive confidence in its presence in the Chahgonbad Formation. Wennanoceras has been reported from North China and the Jingunsan Formation of Taebaek, South Korea (Yun 2011). Yun (2011) regarded the cephalopod fauna of the Jingunsan Formation as having affinities with both North China and Baltica. The true nature of the specimen referred to here as $\mathrm{Al}$ lumettoceras? sp. could turn out to be Pseudowutinoceras if additional, better-preserved material was available for study. This again would suggest an affinity with North China. Given the small amount of material involved and the difficulties generated by the often poor preservation, the affinities of this fauna must remain somewhat speculative, but it does appear to differ from the Darriwilian assemblages of the Alborz Mountains and may show some affinity with those of North China and South Korea.

\section{Trilobites and tentaculitids}

Trilobites from Unit C2 are too poorly preserved for useful taxonomic determination. The occurrence of Vietnamia cf. teichmulleri (Hamman and Leone 1997) in the upper part of Unit $\mathrm{C} 5$ gives further support to the brachiopod based correlation. This species was originally described by Hammann and Leone (1997) from the Punta Serpeddi Formation (Katian) of Sardinia, the precise age of which is not known. It also occurs in the upper part of the Rann Formation of the northern Oman Mountains in association with Deanaspis goldfussii seftenbergi (Hawle and Corda, 1847) and Dreyfussina cf. D. taouzensis (Destombes, 1972). This trilobite assemblage according to Fortey et al. (2011) is most probably of early Katian age.

Tentaculitids are quite common in the Upper Ordovician (Katian) of Iranian terranes but remain very poorly documented. Recently, a tentaculitid species Costatulites kimi Ghobadi Pour et al. in Ghavidel-Syooki et al. 2015b was described from the upper part of the Seyahou Formation (Katian Stage, the lower part of the Armoricochitina nigerica chitinozoan Zone). There is no doubt about the taxonomic attribution of that taxon, but it differes from the most of the Silurian tentaculitids in having an impuctate shell fabtric. Specimens of Costatulites? sp. from Anarak show distinct similarity to C. kimi in the external shell morphology, but they occur only as the external/internal moulds, therefore characters of shell fabric and the internal shell morphology cannot be verified. While their generic attribution is likely, they differ from $C$. kimi in a considerably smaller shell size and they are probably slightly older, because of co-occurrence with the brachiopod Rostricellula cf. ambigena suggesting the early Katian age.

\section{SYSTEMATIC PALAEONTOLOGY}

\section{Brachiopods (L.E. Popov, L.E. Holmer and C. Baars)}

Measurements (in millimetres if not stated otherwise) are as follows: Lv - ventral valve lengh; $\mathrm{Ld}$ - dorsal valve length; $\mathrm{W}$ - maximum valve width; $\mathrm{T}$ - valve depth/thicknes of the shell; S1 - length of dorsal median ridge/septum, s - standard deviation, $\mathrm{n}$ - number of measurements.

Order Strophomenida Öpik, 1934

Superfamily Strophomenoidea King, 1846

Family Rafinesquinidae Schuchert, 1893

Subfamily Rafinesquininae Schuchert, 1893

\section{Genus Hibernodonta Harper and Mitchel in Harper} et al., 1985

TYPE SPECIES: By original designation; Hibernodonta praeco Harper and Mitchel in Harper et al. 1985 from the Clashford House Formation (Upper Ordovician, Katian) of Ireland.

REMARKS: In our assignment of Hibernodonta to the family Family Rafinesquinidae we follow Cocks and Rong (2000). Nevertheless, these authors have mentioned in the generic diagnosis that the genus has an intermediate position between rafinesquinids, and lep- 
tostrophiids. Further discussion of the taxonomic position of this genus within the Strophomenoidea may be found in Rong and Cocks (1994) and GhavidelSyooki et al. (2015a).

\section{Hibernodonta lakhensis sp. nov.} (Text-fig. 6A-K)

DERIVATION OF NAME: After the Lakh Mountains to the north-west of the type locality.

HOLOTYPE: NMW2012.7G.128, dorsal internal mould (Text-fig. 6I), Upper Ordovician, Katian, Chahgonbad Formation, sample AF-8/1, Pol-e Khavand area, Central Iran.

PARATYPES: NMW 2012.7G. 150-168, 173,176178, NMW2014.6G.240 (Text-fig. 6E; Lv = 19.1, W $=22.8$ ), 17 ventral external moulds, NMW 2012.7G. $129,130,174,175$, four ventral internal moulds from sample AF-7/0; NMW 2012.7G. 339 (Text-fig. 6K; Lv $=14.0, \mathrm{~W}=18.2)$, ventral internal mould, NMW 2012.7G.337 (Fig. 6J), 338, dorsal internal mould, sample 7/1; NMW 2012.7G.134 (Text-fig. 6B; Lv = $8.0, \mathrm{~W}=9.3), 137,138$, three ventral external moulds; NMW 2012.7G. 131 (Text-fig. 6A), 132 (Text-fig. $6 \mathrm{C} ; \mathrm{Lv}=6.5, \mathrm{~W}=9.2$ ), 133 (Text-fig. $6 \mathrm{G} ; \mathrm{Lv}=11.8$, $\mathrm{W}=17.3)$, three ventral internal moulds from sample AF-7/2; NMW 2012.7G.239 (Text-fig. 6H; Ld = 10.5, $\mathrm{W}=12.9$ ), dorsal internal mould; NMW 2012.7G. 201-204, 206-213, 335, eight ventral external and four internal moulds; NMW 2012.7G. 127 (Text-fig. $6 \mathrm{~F}$ ), dorsal internal mould from sample AF-8/1; total 40 ventral and three dorsal valves.

DIAGNOSIS: Small for the genus; shell planoconvex, slightly transverse, subrectangular in outline; radial ornament parvicostellate with $9-10$ ribs per $2 \mathrm{~mm}$. Ventral interior with vestigial dental plates and a poorly defined muscle field open anteriorly. Dorsal interior with a faint, bilobed cardinal process and narrow, straight, widely divergent socket ridges.

DESCRIPTION: Shell planoconvex, about three-fourths as long as wide with maximum width at the hinge line or slightly anterior to the hinge line. Cardinal extremities right angled to slightly obtuse. Anterior commissure rectimarginate. Ventral valve lateral profile gently convex with the maximum height at about one-third valve length from the umbo. Ventral interarea low, planar, anacline with a minute pseudodeltidium. Dorsal valve flattened; dorsal interarea low, anacline with a small, convex chilidium. Radial ornament finely parvicostel- late with 9-10 parvicostellae per $2 \mathrm{~mm}$. Three to five parvicostellae intervening between accentuated ribs. Concentric ornament of fine densely spaced fila.

Ventral interior with transverse denticulate teeth and vestigial dental plates. Ventral muscle field poorly defined. Cardinal process bilobed with elongate, divergent lobes completely separated at their bases and minute, straight, widely divergent socket ridges with denticulate outer sides. No dorsal median ridge.

REMARKS: This species assigned to Hibernodonta because it has a cardinalia with strong lobes, a large, open ventral muscle field, teeth with a denticulate posterior surface and completely lacks a dorsal median ridge. It differs from the type species Hibernodonta praeco in having finely parvicostellate ornament, less prominent lobs of the cardinal process and strongly reduced dental plates, as well as a complete absence of concentric rugellae and of a ridge between cardinal process lobes. It is possible that some early species of Eostropheodonta described by Havlíček (1971) may belong to Hibernodonta, but they require further study. Hibernodonta lakhensis sp. nov. recalls Eostropheodonta intermedia Havlíček, 1971 from the Hirnantian Upper Kataoua Formation of Antiatlas, Morocco in the character of radial ornament, but differs in having vestigial dental plates and poorly defined ventral muscle field.

Order Billingsellida Schuchert, 1893

Superfamily Polytoechidea Öpik, 1934

Family Tritoechiidae Ulrich and Cooper, 1936

Genus Tritoechia Ulrich and Cooper, 1936

TYPE SPECIES: By original designation; Deltatreta typica Schuchert and Cooper, 1932 from the Lower Ordovician, Arbuckle Limestone of Oklahoma, USA.

\section{Tritoechia sp. (Text-fig. $7 \mathrm{~A}-\mathrm{C}$ )}

MATERIAL: Middle Ordovician, Darriwilian, Chahgonbad Formation; NMW2012.7G.107 (Text-fig. 7A; $\mathrm{Lv}=17.4, \mathrm{Ld}=17.4, \mathrm{~W}=19.2, \mathrm{~T}=9.8)$, NMW2012.7G.108 (Text-fig. 7B), two articulated shells; NMW2012.7G.111 (Text-fig. 7C; Ld = 14.8, W $=21.8, \mathrm{Iw}=15.5, \mathrm{Sl}=9.1$ ), dorsal internal mould from sample ' $\mathrm{F}$ '.

DESCRIPTION: Shell slightly ventribiconvex, slightly transverse, subrectangular in outline, about two-fifths as thick as long. Hinge line about $70 \%$ of maximum shell width at about mid-length; cardinal extremities 
broadly rounded. Ventral valve lateral profile subpyramidal with maximum height slightly anterior to the apex. Anterior commissure rectimarginate. Ventral interarea high, planar, steeply apsacline to almost catacline. Delthyrium covered by the narrow, convex, apically perforated pseudodeltidium. Dorsal valve lateral profile moderately convex, with maximum height slightly posterior to mid-length. Dorsal interarea almost orthocline with a notothyrium mainly covered by chilidial plates. Radial ornament multicostellate with 4-5 rounded ribs per $2 \mathrm{~mm}$.

Ventral valve interior with long, thin, subparallel dental plates. Ventral muscle field strongly elongate, subrectangular extending anteriorly up to two-fifths sagittal valve length and mainly confined to the delthyrial cavity floor. Ventral mantle system not observed. Dorsal valve interior, with a high, subtriangular notothyrial platform bisected by a ridge-like cardinal process and broad, transverse socket plates occupying more than half maximum shell width. Dorsal adductor muscle scars weakly impressed, bisected by a high median ridge extending anteriorly to the mid-valve.

REMARKS: These shells differ from other Darriwilian species of the genus, e. g. Tritoechia billingsi Neuman, 1968, from the Shin Brook Formation of New Brunswick, Canada, Tritoechia crassa Popov et al., 2001 from the Uzunbulak Formation of the Chu-Ili Range in South Kazakhstan and Tritoechia chuannanensis Zhan and Jin., 2005a, from the Dashaba Formation of Sichuan Province of South China, in possessing a large, elongate ventral muscle field occupying almost two-fifths of valve length and bordered laterally by long sublarallel dental plates. In addition Iranian specimens have a rectimarginate anterior commissure and a moderately convex dorsal valve unlike Tritoechia crassa, as well as a subpyramidal ventral valve and well developed chilidial plates unlike Tritoechia chuannanensis. Specimens of Tritoechia from the Chahgonbad Formation are probably a new taxon; however, the state of preservation of the available material is not satisfactory enough for a formal designation.

Order Orthida Schuchert and Cooper, 1932

Suborder Orthidina Schuchert and Cooper, 1932

Superfamily Orthoidea Woodward, 1852

Family Glyptorthidae Schuchert and Cooper, 1931
Genus Lomatorthis Williams and Carry, 1985

TYPE SPECIES: By original designation; Lomatorthis mimula Williams and Carry, 1985, Middle Ordovician, upper Dapingian, Tourmakeady Limestone Formation, Tourmakeady, Co. Mayo, Ireland.

\section{Lomatorthis? multilamellosa sp. nov. (Text-figs $6 \mathrm{~L}, 7 \mathrm{H}-\mathrm{K}$ )}

DERIVATION OF NAME: After the lamellose concentric ornament of the shell.

HOLOTYPE: NMW2012.7G.124 (Text-fig. 7K; Lv= $17.0, \mathrm{Ld}=15.0, \mathrm{Ml}=6.0, \mathrm{Mw}=6.2, \mathrm{Sl}=7.0$ ), internal mould of a pair of conjoined valves; Middle Ordovician, Darriwilian, Chahgonbad Formation, sample 'F', area $21 \mathrm{~km}$ SE of Anarak, Pol-e Khavand area, Central Iran.

PARATYPES: Locality and horizon as for the holotype; NMW2012.7G.104 (Text-fig. 7H; Lv = 17.3, W $=16.5, \mathrm{Iw}=16.2, \mathrm{Ml}=5.6, \mathrm{Mw}=5.8)$, internal mould of a pair of conjoined valves; NMW2012.7G.126 (Text-fig. 7I), NMW2012.7G.125 (Text-fig. 7J), dorsal external moulds, 140, exfoliated ventral valve, 333 (Text-fig. 6L), dorsal external mould.

DIAGNOSIS: Distinctly ventribiconvex shell about four-fifths as long as wide with saccate ventral mantle canals. Ventral branches of vascula media subparallel, running close to each other. Dorsal adductor scars quadripartite with a slightly larger anterior pair.

DESCRIPTION: Shell ventribiconvex with flattened and resupinate outer shell margins variably curved dorsally, about four-fifths as long as wide. Hinge line about two-thirds as wide as maximum shell width at mid-length, cardinal extremities obtuse. Anterior commissure rectimarginate. Ventral valve lateral profile moderately convex with maximum height at about onethird sagittal valve length from the umbo. Ventral interarea curved, apsacline with a narrow, triangular, open delthyrium. Dorsal valve gently convex in the posterior half becoming flattened and then weakly curved dorsally along the outer margins. Ventral interarea low, anacline with an open notothyrium. Radial ornament ramicostellate with 6 angular ribs per $3 \mathrm{~mm}$ at $5 \mathrm{~mm}$ from the umbo and 4-5 ribs per $2 \mathrm{~mm}$ along the

Text-fig. 6. Brachiopods from Upper Ordovician Chahgonbad Formation. A-K - Hibernodonta lakhensis sp. nov.; A - NMW2014.7G.131, latex cast of ventral valve exterior, sample, sample AF-7/2; B - NMW2012.7G.134, latex cast of ventral valve exterior, sample AF-7/2; C - NMW2014.6G.132, latex cast of dorsal valve exterior, sample AF-7/0; D - NMW2012.7G.133, latex cast of ventral valve exterior, sample AF-7/2; E - NMW2012.7G.240, latex cast of ventral valve exterior, sample AF-7/0; F - NMW2012.7G.127, latex cast of dorsal valve interior, sample AF-8/1; G 1 , G 2 - NMW2012.7G.133, ventral internal mould, latex 
ORDOVICIAN OF CENTRAL IRAN
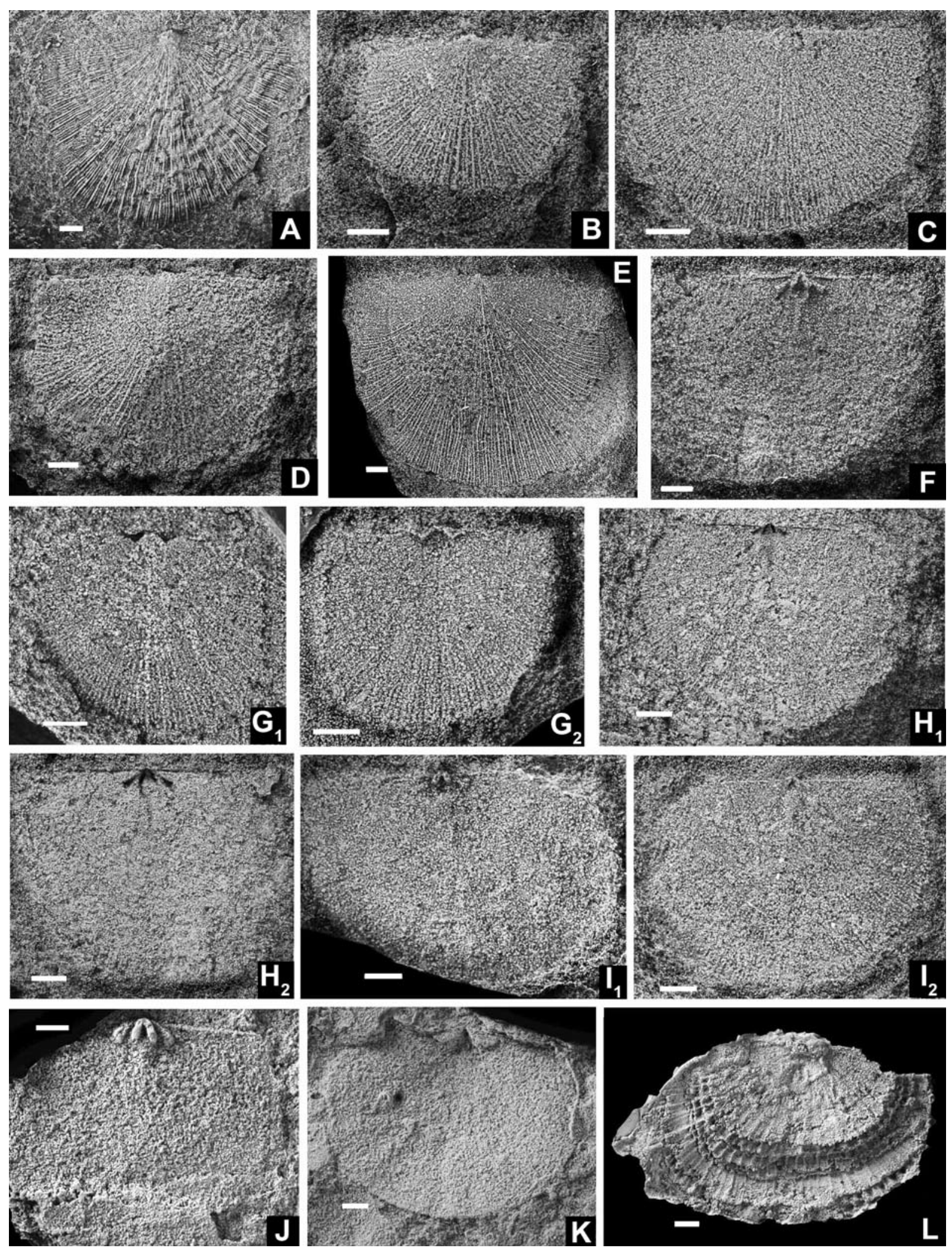

cast of interior, sample AF-7/2; $\mathrm{H}_{1}, \mathrm{H}_{2}-\mathrm{NMW} 2014.7 \mathrm{G} .239$, latex cast of dorsal interior, sample AF-7/0; $\mathrm{I}_{1}, \mathrm{I}_{2}-\mathrm{NMW} 2012.7 \mathrm{G} .128$, holotype, dorsal internal mould, latex cast of interior, sample 8/1; J - NMW2012.7G.337, latex cast of dorsal interior, sample 7/1; K - MW2012.7G.339, latex cast of ventral interior, sample 7/1. L-Lomatorthis? multilamellosa sp. nov., NMW2012.7G.333, latex cast of dorsal interior, sample 'F'. All scale bars are $2 \mathrm{~mm}$. 

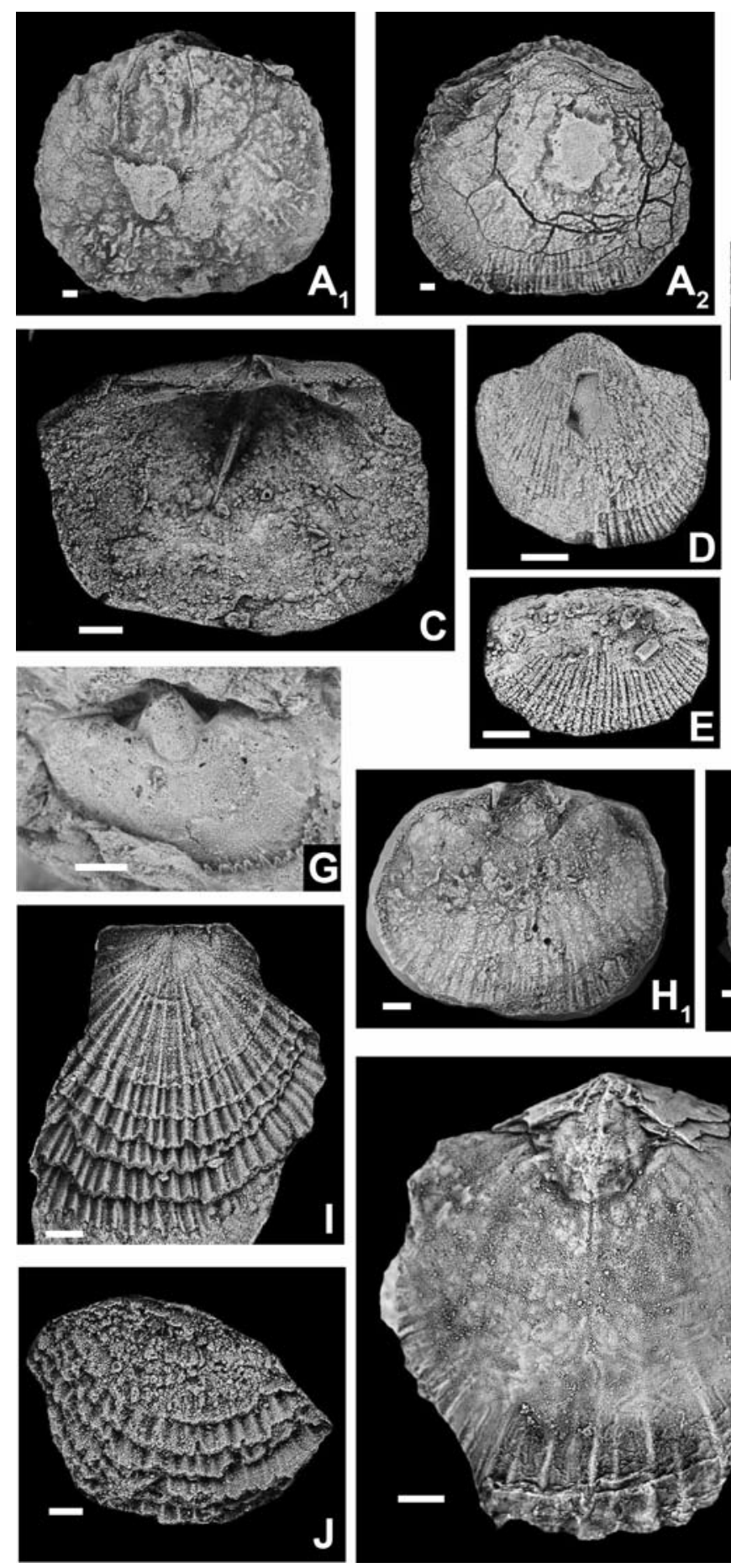

C
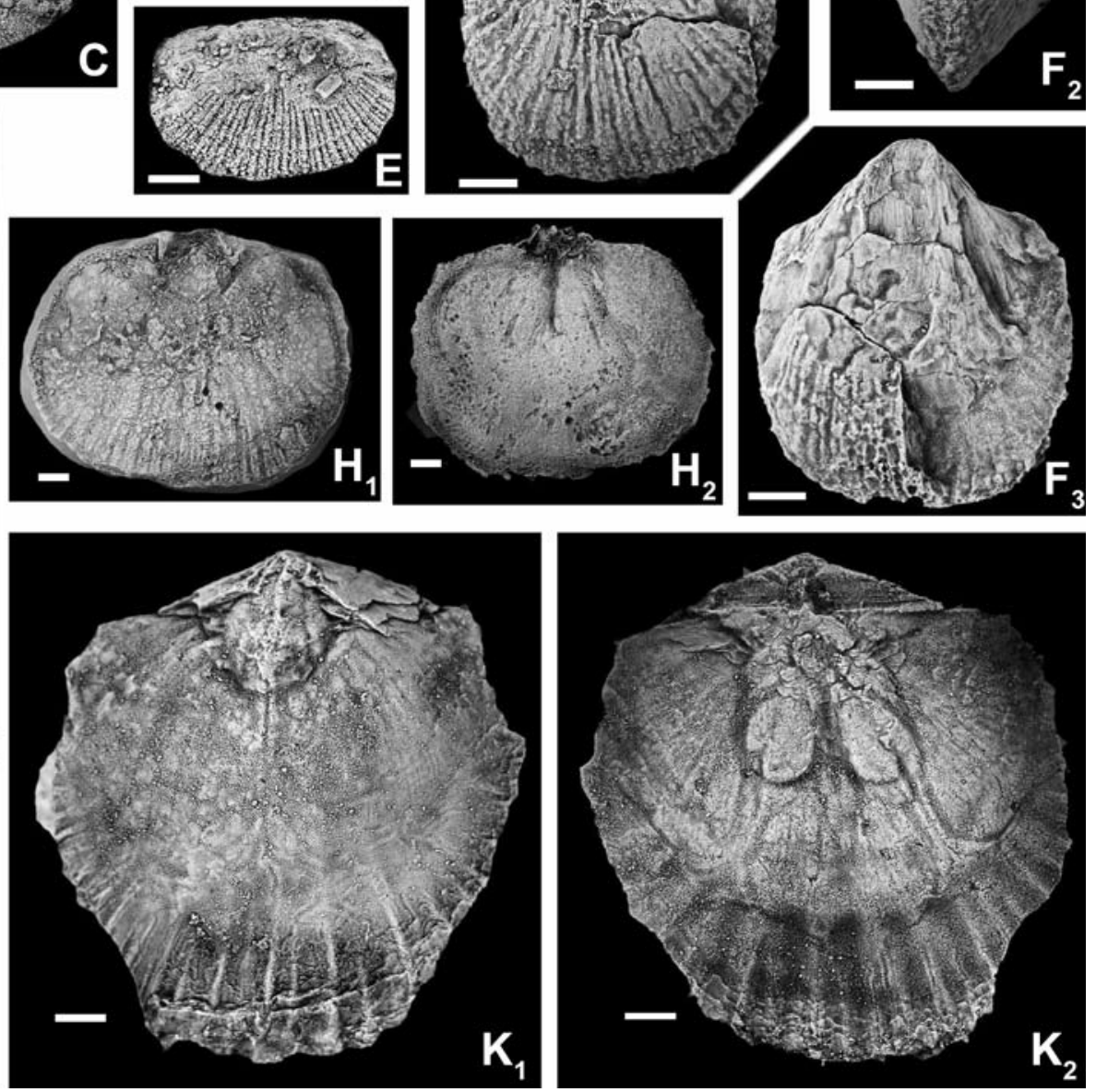

Text-fig. 7. Brachiopods from Middle Ordovician, Darriwilian, Chahgonbad Formation. A-C - Tritoechia sp., sample 'F'; A 1 - $\mathrm{A}_{4}$ - NMW2012.7G.107, pair of exfoliated conjoined valves, ventral, dorsal, posterior and lateral views; B - NMW2012.7G.108, a pair of conjoined valves, posterior view showing pseusodeltidium; C - NMW2012.7G.111, latex cast of dorsal valve interior. D-F - Phragmorthis sp.; D - NMW2012.7G.314, ventral valve exterior, latex cast; E - NMW2012.7G.350, dorsal valve exterior, latex cast; $\mathrm{F}_{1}-\mathrm{F}_{3}-\mathrm{NMW} 2012.7 \mathrm{G} .113$, a pair of conjoined valves, dorsal, lateral and ventral views; G - NMW2012.7G.332, ventral valve internal mould. H-K - Lomatorthis? multilamellosa sp. nov.; $\mathrm{H}_{1}, \mathrm{H}_{2}-\mathrm{NMW} 2012.7 \mathrm{G} .104$, internal mould of a pair of conjoined valves, ventral and dorsal views; I - NMW2012.7G.126, latex cast of dorsal exterior; J - NMW2012.7G.125, latex cast of dorsal interior; $\mathrm{K}_{1}$, $\mathrm{K}_{2}$ - NMW2012.7G.124, holotype, internal mould of 
anterior margin of lager shells. Concentric ornament with numerous lamellose frills in the anterior half of the shell and very fine densely spaced concentric fila.

Ventral interior with thin divergent dental plates and slightly elongate, suboval muscle field about $30 \%$ as long as the valve, with wide, triangular adductor scar raised anteriorly, flanked by shorter, gently impressed diductor scars. Ventral mantle canals saccate with long, subparallel vascula media placed close to each other. Dorsal interior with a low, subtriangular notothyrial platform and short, divergent brachiophores. Cardinal process not observed. Dorsal adductor scars gently impressed, quadripartite with a slightly larger anterior pair, bisected by low median ridge about twofifths as long as the valve.

DISCUSSION: The Iranian shells assigned to Lomatorthis, because they have an elongate ventral muscle field situated on the elevated platform, with a broad adductor scar longer than diductor scars, a resupinate dorsal valve, and a concentric ornament of numerous lamellose frills. However, they differ from the type species Lomatorthis mimula in having, a distinctly ventribiconvex shell and dorsal adductor scars with larger anterior components. The ventral mantle canals in Lomatorthis mimula and the cardinal process in Lomatorthis? multilamellosa are unknown, therefore the generic affiliation of the Iranian shells is somewhat provisional.

Family Cremnorthidae Williams, 1963

Genus Phragmorthis Cooper, 1956

TYPE SPECIES: By original designation; Phragmorthis buttsi Cooper, 1956, from Effna-Rich Valley Formation of Virginia, USA.

\section{Phragmorthis? sp. \\ (Text-fig. 7D-F)}

MATERIAL: Middle Ordovician, Darriwilian, Chahgonbad Formation; NMW2014.6G.43, 113 (Text-fig. $7 \mathrm{~F} ; \mathrm{Lv}=10.8, \mathrm{Ld}=9.2, \mathrm{~W}=9.6, \mathrm{Iw}=8.5, \mathrm{~T}=5.6$ ), articulated shells, NMW2012.7G.332 (Text-fig. 6G) ventral internal mould, NMW2012.7G.314 (Text-fig. 7D), 349, ventral external moulds, NMW2012.7G.350 (Text-fig. 7E), dorsal external mould, 114, ventral internal mould from sample ' $F$ '.

REMARKS: These dorsibiconvex shells resemble closely the specimens of Phragmorthis recently discovered from the Darriwilian Lashkarak Formation in eastern Alborz, which are currently under study, in having a multicostellate ornament, an unisulcate anterior commissure and a ventral muscle field on the pseudospondilium. Shells from Alborz have a characteristic blade-like dorsal median septum; however, the dorsal interior of the specimens from the Chahgonbad Formation remains unknown, which makes their generic determination provisional.

Order Pentamerida Schuchert and Cooper, 1931

Suborder Syntrophiidina Ulrich and Cooper, 1936

Superfamily Syntrophioidea Ulrich and Cooper, 1936

Family Clarkellidae Schuchert and Cooper, 1931

Genus Yangtzeella Kolarova, 1925

TYPE SPECIES: By original designation; Schizophoria poloi Martelli, 1901, Middle Ordovician, Dawan Formation, Hubei Province, South China.

Yangtzeella chupananica sp. nov. (Text-fig. 8B-F)

DERIVATION OF NAME: After Chupanan Rural District; the area in which the fossil locality is located.

HOLOTYPE: NMW2012.7G.105 (Text-fig. 8B; Ld = $17.8, \mathrm{~W}=16.2, \mathrm{~T}=5.6$ ), dorsal internal mould, Middle Ordovician, Darriwilian, Chahgonbad Formation, sample 'F', area $21 \mathrm{~km} \mathrm{SE}$ of Anarak, Pol-e Khavand area, Central Iran.

PARATYPES: Locality and horizon as for the holotype; NMW2014.7G.122 (Text-fig. 8C; Lv = 16.2, Ld $=15.2, \mathrm{~W}=20.5, \mathrm{~T}=7.7$ ), a pair of conjoined valves; NMW2014.6G.110 (Text-fig. 8E) ventral internal mould; NMW2014.6G.118 (Text-fig. 8D), NMW2012.67G.106 (Text-fig. 8F), 117, 123, dorsal internal moulds.

OTHER MATERIAL: Locality and horizon as for the holotype; NMW 2014.7G.141-149, 4 four ventral and three dorsal valves; NMW 2012.7G.351, ventral internal mould. Total one pair of conjoined valves, six ventral and six dorsal valves.

DIAGNOSIS: Shell small for the genus, subcircular in outline with a weakly developed dorsal median fold and ventral sulcus originating at mid-length. Ventral interior with a large spondylium supported by the short median septum. Dorsal interior with a delicate subtriangular pseudoseptalium, a thin, blade-like crura and a prominent median septum. 
DESCRIPTION: Shell slightly dorsibiconvex, subcircular, almost as long as wide with maximum width at mid-length, and slightly more than two-fifths as thick as long. Hinge line straight, about half maximum shell width. Anterior commissure gently uniplicate. Ventral valve lateral profile moderately convex with maximum height at about two-fifths valve length from the umbo. Interarea low, strongly apsacline to almost orthocline, with open, triangular delthyrium. Sulcus originating at mid-length, gradually deepening anteriorly and terminated with a low, semioval tongue. Dorsal valve lateral profile evenly convex with maximum height at, or slightly anterior to mid-length. Median fold poorly defined from lateral sides of the valve, becoming prominent only near the anterior margin of large individuals. Shell surface apparently smooth, radial capillae not observed, probably due to exfoliation of the shell surface.

Ventral interior with strong teeth and a large spondylium supported by a short, thick median septum terminating anterior to mid length. Mantle canals weakly impressed. Dorsal interior with a subtriangular, highly raised pseudoseptalium, deep sockets bounded by prominent inner socket ridges, and high, divergent inner hinge plates about two-fifths as long as the valve. Crura thin, blade-like, with evenly rounded terminations. Adductor muscle field situated on a pair of small, elevated, transverse platforms supported by the inner hinge plates. Adductor muscle scars radially arranged. Dorsal median septum prominent, as long as hinge plates. Mantle canals pinnate with individual branches separated by high, radially arranged ridges.

REMARKS: Yangtzeella chupananica sp. nov. differs from another Iranian species Yangtzeella longiseptata Ghobadi Pour et al., 2011, which occurs in the Floian of Eastern Alborz, in having a weakly developed ventral sulcus and dorsal median fold, a larger spondylium, supported by the short median septum, thin, blade-like crura and a more prominent dorsal median ridge. It differs from two other Darriwilian species of the genus, namely Yangtzeella kueiyangensis Yoh, 1945, from the Kuniutan Formation of central Guizhou in South China and Yangtzeella igori Nikitina et al., 2006, from the Uzunbulak Formation of Chu-Ili Range in South Kazakhstan, in possessing a subcircular shell with a weakly developed ventral sulcus and a dorsal median fold originating not in the umbonal area, but at shell mid-length.

Superfamily Camerelloidea Hall and Clarke, 1895

Family Camerellidae Hall and Clarke, 1895

Subfamily Camerellinae Hall and Clarke, 1895
Genus Camerella Billings, 1859

TYPE SPECIES: By original designation; Camerella volborthi Hall and Clarke, 1893, from Middle Ordovician, upper Darriwilian, Rockland Formation, Ontario, Canada.

Camerella? sp.

(Text-fig. 8A)

MATERIAL: NMW2012.7G.112 (Text-fig. 8A; Lv = 9.7, $\mathrm{Ld}=9.9, \mathrm{~W}=10,9, \mathrm{~T}=5.5)$, a pair of conjoined valves from sample ' $F$ '.

REMARKS: In having subequally biconvex, subcircular shell about $90 \%$ as long as wide with a radial ornament of 13 rounded ribs that become prominent only at the shell margin, the specimen from the Chahgonbad Formation recalls Camerella mica Nikitina et al. 2006 from the Darriwilian, Uzunbulak Formation of the Chu-Ili Range in South Kazakhstan, but it is more than twice as large. The interior of both valves in the Iranian specimen is unknown except for a trace of the median septum in the umbonal area of the ventral valve (Text-fig. 8 $\mathrm{A}_{1}$ ) suggesting the presence of the spondylium. Therefore attribution of the specimen to Camerella is likely, but species determination is impossible.

There are two more Darriwilian species with a similar external shell morphology and radial ornament originating close to the shell margins described under the names Rhynchocamara? acuminata (Pander, 1830) by Rubel (1961) from the Obukhovo Formation of St Petersburg Region in the East Baltic and Karakulina nana Andreeva, 1972 from Karakul Formation of South Urals. Both taxa remain inadequately known. The most recent discussion of their possible affinities was given by Popov et al. (2005).

Order Rhynchonellida Kuhn, 1949

Superfamily Rhynchotrematoidea Schuchert, 1913

Family Trigonirhynchiidae Schmidt, 1965

Subfamily Rostricellulinae Rozman, 1969

Genus Rostricellula Ulrich and Cooper, 1942

TYPE SPECIES: By original designation; Rostricellula rostrata Ulrich and Cooper, 1942, from Upper Ordovician (Sandbian) Lebanon Formation, Tennessee, USA

Rostricellula cf. ambigena Havliček, 1961 (Text-figs 9D, E; 15D)

MATERIAL: NMW 2012.7G.348.1 (Text-fig. 9D), 
ORDOVICIAN OF CENTRAL IRAN

ventral external mould, NMW 2012.7G.348.2 (Textfig. 9E), dorsal external mould, NMW 2012.7G.242.13 , two ventral and one dorsal internal and external moulds from sample 7/0; NMW 2012.7G.354.2-3, ventral external moulds from sample $7 / 2$.
REMARKS: These few, small, subtriangular rhynchonellide shells with a single rib in the ventral sulcus, two ribs on the dorsal fold and 6-7 ribs on flanks of both valves strongly recall specimens of Rostricellula ambigena from the uppermost Lower Ktaoua and lower part
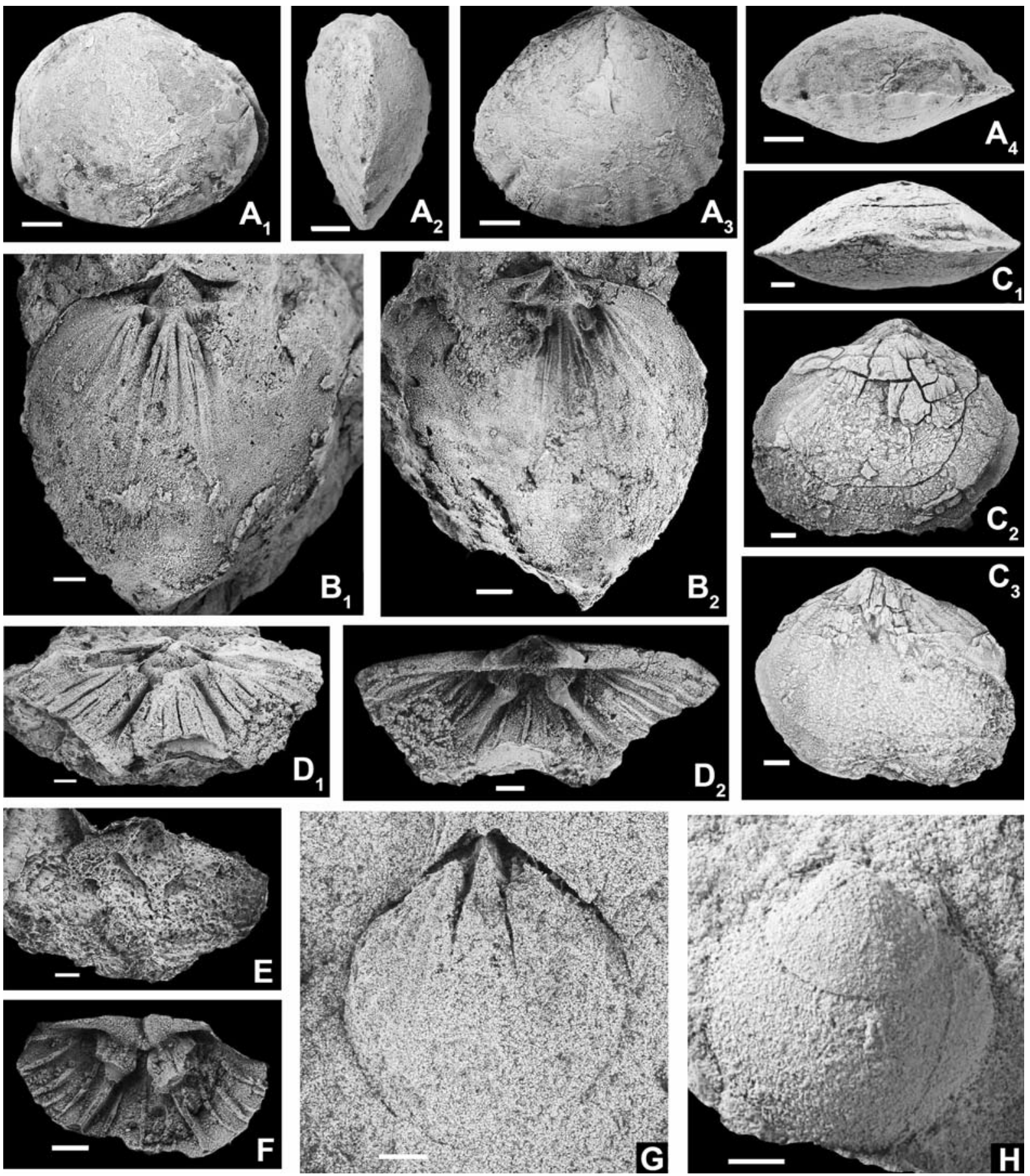

Text-fig. 8. Brachiopods from Middle to Upper Ordovician Chahgonbad Formation. A 1 -A 4 - Camerella sp., sample 'F'; NMW 2012.7G.112, a pair of conjoined valves ventral, lateral, dorsal and anterior views. B-F, Yangtzeella chupananica sp. nov., sample 'F'; $\mathrm{B}_{1}$, $\mathrm{B}_{2}$ NMW2012.7G.105, holotype, dorsal internal mould; $\mathrm{C}_{1}-\mathrm{C}_{3}-\mathrm{NMW} 2014.7 \mathrm{G} .122$, a pair of conjoined valves, anterior, dorsal and ventral views; $\mathrm{D}_{1}, \mathrm{D}_{2}-\mathrm{NMW} 2012.7 \mathrm{G} .118$, dorsal internal mould and latex cast of interior; E - NMW 2012.7G.110, ventral internal mould, F - NMW 2012.7G.106, dorsal internal mould. G, H - Hindella prima sp. nov.; G - NMW 2012.7G.336, ventral internal mould, sample AF-7/2; H - NMW2012.7G.334, latex cast of ventral valve exterior, sample AF-7/2. All scale bars are 2 mm 

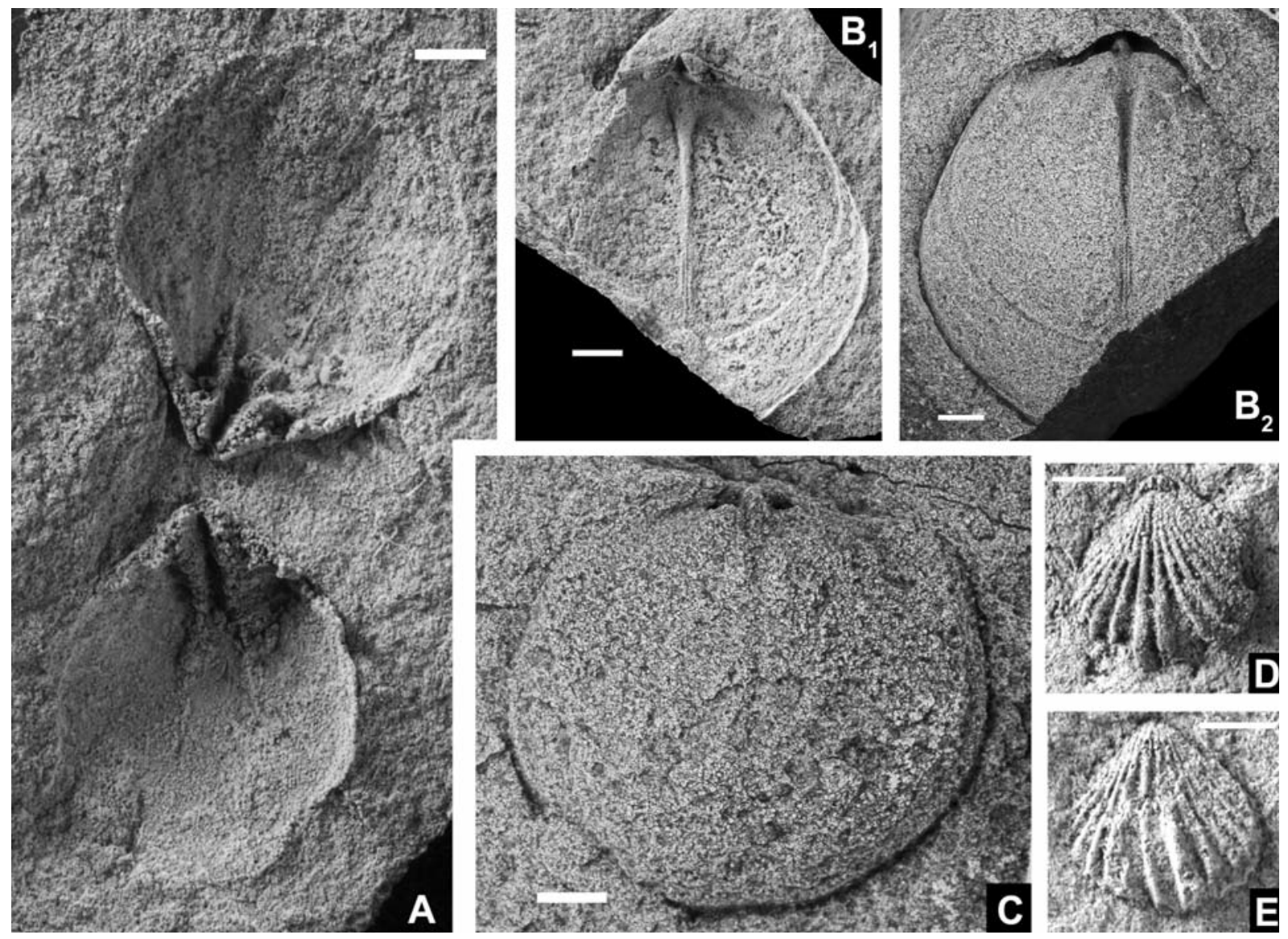

Text-fig. 9. Brachiopods from Upper Ordovician (Katian) Chahgonbad Formation. A-C - Hindella prima sp. nov.; A - NMW 2012.7G.355, 356, latex casts ventral valve interior, sample 8/1; B , B $_{2}$ - NMW 2012.7G.352, dorsal internal mould, sample AF-7/0; C - NMW 2012.7G.353, dorsal internal mould, sample AF7/0; D, E-Rostricellula cf. ambigena Havliček, 1961, sample AF-7/0; D - NMW 2012.7G.348.1, latex cast of dorsal valve exterior; E - NMW 2012.7G.348.2, latex cast of ventral valve exterior. All scale bars are $2 \mathrm{~mm}$

of the Upper Tiouririne formations of the Anti-Atlas, Morocco illustrated by Colmenar and Álvaro (2014, figs 8f, 9e, f). By comparison with the topotypes of Rostricellula ambigena described and illustrated by Havliček (1961) the specimens from the Chahgonbad Formation are considerably smaller and lack the pair of secondary ribs, which appear in some Bohemian specimens.

Order Athyridida Boucot, Johnson and Staton, 1964 Suborder Athyrididina Boucot, Johnson and Staton, 1964 Superfamily Meristelloidea Waagen, 1883 Family Meristellidae Waagen, 1883 Subfamily Meristellinae Waagen, 1883

Genus Hindella Davidson, 1882

TYPE SPECIES: By original designation; Athyris umbonata Billings, 1862, from Ellis Bay Formation (Hirnantian), Anticosti Island, Quebec, Canada.
Hindella prima sp. nov.

(Text-figs 8G, H; 9A-C; 15E)

DERIVATION OF NAME: Latin, primus, nearest, next.

HOLOTYPE: NMW 2012.7G. 336 (Text-fig. 8G, Lv $=10.5, \mathrm{~W}=11.2, \mathrm{~T}=3.2$ ), ventral internal mould; Upper Ordovician, Katian, Chahgonbad Formation, sample AF-7/2, area about $21 \mathrm{~km}$ south-east of Anarak, Pol-e Khavand area, Central Iran

PARATYPES: NMW 2012.7G.169, 170, 241, ventral internal moulds, NMW 2012.7G.171, 172, ventral external moulds, NMW 2012.7G.181-183, 352 (Text-fig. 9B), 353 (Fig. 9C; $\mathrm{Ld}=10.2, \mathrm{~W}=14.5, \mathrm{~T}=2.3$ ), dorsal internal moulds, sample 7/0; NMW 2012.7G.185, exfoliated ventral valve, NMW 2012.7G.225-234, ventral internal moulds, NMW2012.7G.334 (Text-fig. 8H; Lv $=9.9, \mathrm{~W}=10.0, \mathrm{~T}=3.6$ ), ventral external mould, NMW 
2012.7G.235, dorsal internal mould, NMW 2012.7G.139, dorsal external mould from sample 7/2; NMW 2012.7G. 355, 356 (Text-fig. 9A), ventral internal moulds; 357, ventral internal moulds, NMW 2012.7G. 205, 236, dorsal internal moulds, Sample 8/1; NMW 2012.7G.238 (Text-fig. 15E; Lv = 15.5, W = 13.2 ,), ventral external mould from sample $8 / 2$; plus four ventral and four dorsal external and internal moulds, from sample 9/1. Total 23 ventral and 12 dorsal valves.

DESCRIPTION: Shell slightly ventribiconvex, slightly elongate suboval to almost circular in outline $104 \%$ (s = $10 \%, \mathrm{n}=5$ ) with maximum width at mid-length. Anterior commissure rectimarginate. Ventral valve strongly convex about one-third as deep as long with the maximum height slightly posterior to mid-length. Ventral umbo strongly swollen, gently incurved. Dorsal valve almost as long as wide, moderately and evenly convex, about one-fourth as deep as long, umbo inconspicuous. Shell surface smooth except for occasional strong growth marks.

Ventral interior with strong cyrtomatodont teeth supported by strong dental plates slightly divergent anteriorly and terminated slightly anterior to mid-length. Pedicle callist strongly thickened, elongate subtriangular. Ventral muscle field narrow, elongate, triangular, open anteriorly and flanked laterally by the long dental plates. Individual muscle scars and mantle canals not impressed. Dorsal interior with a delicate, disjunct hinge plate not exceeding one-quarter valve maximum width. Septalium narrow and shallow, formed by minute septal plates converged on the low posteriorly thickened median septum extending anteriorly slightly beyond bid-length. Sockets long, narrow, widely divergent. Adductor muscle scars and mantle canal impressions indiscernible. Brachial supports and jugum unknown.

REMARKS: Shells from the Chahgonbad Formation can be easily distinguished from the type species Hindella umbonata Billings, as well as from Hindella cassidea (Dalman, 1828), as revised by Sheehan (1977) from the Hirnantian of Sweden, and Hindella crassa incipiens (Williams, 1951), which achieved an almost cosmopolitan distribution during the Hirnantian. H. prima has a less inflated shell, longer dental plates, a narrow hinge plate not exceeding more than one-quarter valve width, a minute, shallow septalium, and a not strongly incurved ventral beak.

The new species differs from Hindella terebratulina (Wahlenberg, 1821) from the Boda Limestone (upper Katian) of Sweden in having a less strongly incurved ventral beak, an inconspicuous dorsal beak, a rectimarginate (not gently uniplicate) anterior commissure, complete absence of ventral sulcus, signifi- cantly longer dental plates and a dorsal median septum which extend slightly beyond the mid-valve.

Cephalopods (D.H. Evans)

Class Cephalopoda Cuvier, 1797

Order Endocerida Teichert, 1933

Family Endoceratidae Hyatt, 1883

Genus Dideroceras Flower in Flower and Kummel, 1950

TYPE SPECIES: By original designation; Endoceras wahlenbergi Foord, 1887, from the Hølen Limestone Formation (Kundan [Darriwilian]) of Kinnekulle, Västergötland, Sweden.

REMARKS: Flower (1964) noted that Dideroceras was characterised by extremely long macrochoanitic septal necks reaching 1.5-2 siphuncular segments in length. Flower (1964) and Balashov (1968) described seventeen taxa that they attributed to Dideroceras, including the type species from the Middle Ordovician of Baltica.

At least nineteen species of Dideroceras have been described from the Baltic region. These show substantial variation in cameral depth and siphuncle diameter; the length and cross-section of the endocones, as well as in the shape and position of the endosiphocone. Many of these species are based on a small number of individuals, whilst the stratigraphical horizons from which they originated are sometimes poorly constrained. Nevertheless, it is clear that the differences in cameral depth and siphuncle diameter are not related to the size of the conch. Some species plot so closely to each other (Textfig. 11) that they are likely to be conspecific, but larger numbers of specimens will be required if a more realistic view of the systematics of the genus is to be achieved.

Dideroceras? sp. 1.

(Text-figs 10 A, B; 13A, D; 14 A, B)

MATERIAL: NMW2014.6G.2, from sample 'E'.

DESCRIPTION: Both specimens consist of short lengths of phragmocone with dorsoventral diameters of $21 \mathrm{~mm}$ (NMW2014.6G.2) and $25 \mathrm{~mm}$ (NMW2014.6G.16). NMW2014.6G.2 exhibits a slightly compressed cross-section that may be a consequence of deformation rather than constituting an original feature. The depth of the septa lies between $23 \%$ and $27 \%$ of the dorsoventral diameter of the phragmocone, whilst the depth of the camerae ranges from $14 \%$ to $17 \%$ of the phragmocone diameter. The siphuncle is marginal in position and almost in contact with the conch wall. Its diameter ranges from $34 \%$ to 
$36 \%$ of the dorsoventral diameter of the siphuncle. The state of preservation of both specimens makes it difficult to interpret the nature of the septal necks. They are macrochoanitic, but only 1.3 to 1.5 siphonal segments in length (Text-figs 13A; 14A). It is not possible to distinguish the connecting rings, but as the septal necks are macrochoanitic, it is assumed that they line the septal necks. Although there appears to be little contrast either in colour or fabric between the contents of the siphuncle and the rest of the matrix, the weathered apical surfaces of siphuncle of both specimens indicate that endosiphuncular deposits are present, as a series of concentric ridges can be seen, and in a polished transverse section of the apical end of NMW2014.6G.2 the faint races of endocones and a circular endosiphotube $0.43 \mathrm{~mm}$ in diameter is visible. The surface of the conch appears to be preserved as a dark iron oxide (possibly haematite) in both specimens, and appears to be entirely smooth.

REMARKS: In the relatively small diameter of siphuncle and the shallow camerae, these specimens compare most closely to Dideroceras amplum Balashov and D. leetense Balashov from the Kundan (Darriwilian) of Estonia. Endosiphuncular deposits have not been described in either species and the septal necks are only clearly illustrated for $D$. amplum, where they are of a similar length to the specimens described above.

Dideroceras? sp. 2

(Text-figs 10C, D; 13C, H; 14C)

MATERIAL: NMW2014.6G.5, 6, from sample 'F'.

DESCRIPTION: Although NMW2014.6G.6 is the larger specimen, consisting of a piece of phragmocone $100 \mathrm{~mm}$ long and about $26 \mathrm{~mm}$ in diameter, it is both corroded and deformed. By contrast, NMW2014.6G.5, which consists of a shorter length of phragmocone (64 $\mathrm{mm})$ and $21 \mathrm{~mm}$ in diameter, is generally better preserved. The estimated apical angle of the two specimens are about 4 and 5 degrees respectively, and the cross-section of the phragmocone in NMW2014.6G.5 is slightly depressed, although this might arise from the deformation of this specimen. The depth of the septa is $27 \%$ of the phragmocone diameter in NMW2014.6G.5 and 24\% in NMW2014.6G.6. Cam- eral depth ranges between $30 \%$ and $47 \%$ of the phragmocone diameter, whilst the diameter of the siphuncle is $26 \%$ of the phragmocone diameter in NMW2014.6G.5 and 25\% in NMW2014.6G.6. The septal necks are only visible in NMW2014.6G.5, where they are macrochoanitic and 1.5 siphuncular segments in length. It is not possible to distinguish the connecting ring, and the presence of shell fragments in the lumen of the siphuncle indicates that no endosiphuncular deposits are present in the preserved length of the phragmocone.

REMARKS: The diameter of the siphuncle in these two specimens is smaller than that known in any other species of Dideroceras, whilst the camerae in NMW2014.6G.5 are also deeper than in other Dideroceras species. In terms of cameral depth and siphuncle diameter, these specimens most closely resemble D. magnum Flower and the specimens attributed to $D$. wahlenbergi (Foord) by Balashov (1968, pl. 35, figs 2, 3).

\section{Dideroceras? sp. \\ (Text-fig. 10J)}

\section{MATERIAL: NMW2014.6G.11, from sample 'F'.}

DESCRIPTION: This specimen consists of a portion of ectosiphuncle $35 \mathrm{~mm}$ long with a depressed cross section, which at the adoral end is $18.5 \mathrm{~mm}$ by 15.5 $\mathrm{mm}$ in diameter. The distance between the septal foraminae is $7.8 \mathrm{~mm}$. The traces of the septal foraminae are slightly inclined (11 degrees) to the normal of the axis of the siphuncle, but form a marked saddle over the venter. A faint ridge is visible in some siphonal segments about a third of the way apically from the septal foraminae, suggesting that the septal necks are macrochoanitic. The lack of any shell debris within the siphuncle, combined with the homogenous nature of the matrix, suggests that the endosiphuncle consists of recrystallised endosiphuncular deposits.

REMARKS: The presence of macrochoanitic septal necks suggests that this specimen is likely to belong to Dideroceras, but it is impossible to compare with other species or the material described above. It is only included here in order to indicate the likely presence of larger endocerid phragmocones in the assemblage.

Text-fig. 10. Cephalopods from the Chahgonbad Formation, sample 'F'. A, B - Dideroceras? sp. 1; $\mathrm{A}_{1}, \mathrm{~A}_{2}-$ NMW2014.6G.2, apical view of phragmocone showing the marginally positioned siphuncle on the ventral side, lateral view, venter on right, $\times 1.18 ; \mathrm{B}_{1}$ - $\mathrm{B}_{3}-\mathrm{NMW} 2014.6 \mathrm{G} .16$, apical (venter down), dorsal and lateral views (venter on left) of phragmocone, $\times 1.18$. C, E - Dideroceras? sp. 2. $\mathrm{C}_{1}, \mathrm{C}_{2}-\mathrm{NMW} 2014.6 \mathrm{G} .5$, ventral and lateral views (venter on left) of phragmocone; $\times 1.41 ; \mathrm{E}_{1}, \mathrm{E}_{2}-\mathrm{NMW} 2014.6 \mathrm{G} .6$, corroded phragmocone, lateral (venter on right) and ventral views with siphuncle exposed on ventral surface, $\times 0.94$. D-G - Wolungoceras? sp.; $\mathrm{D}_{1}, \mathrm{D}_{2}-\mathrm{NMW} 2014.6 \mathrm{G} .3$, dorsal and apical views of phragmocone showing scar of large septal foramen, $\times 1.88$; 
ORDOVICIAN OF CENTRAL IRAN

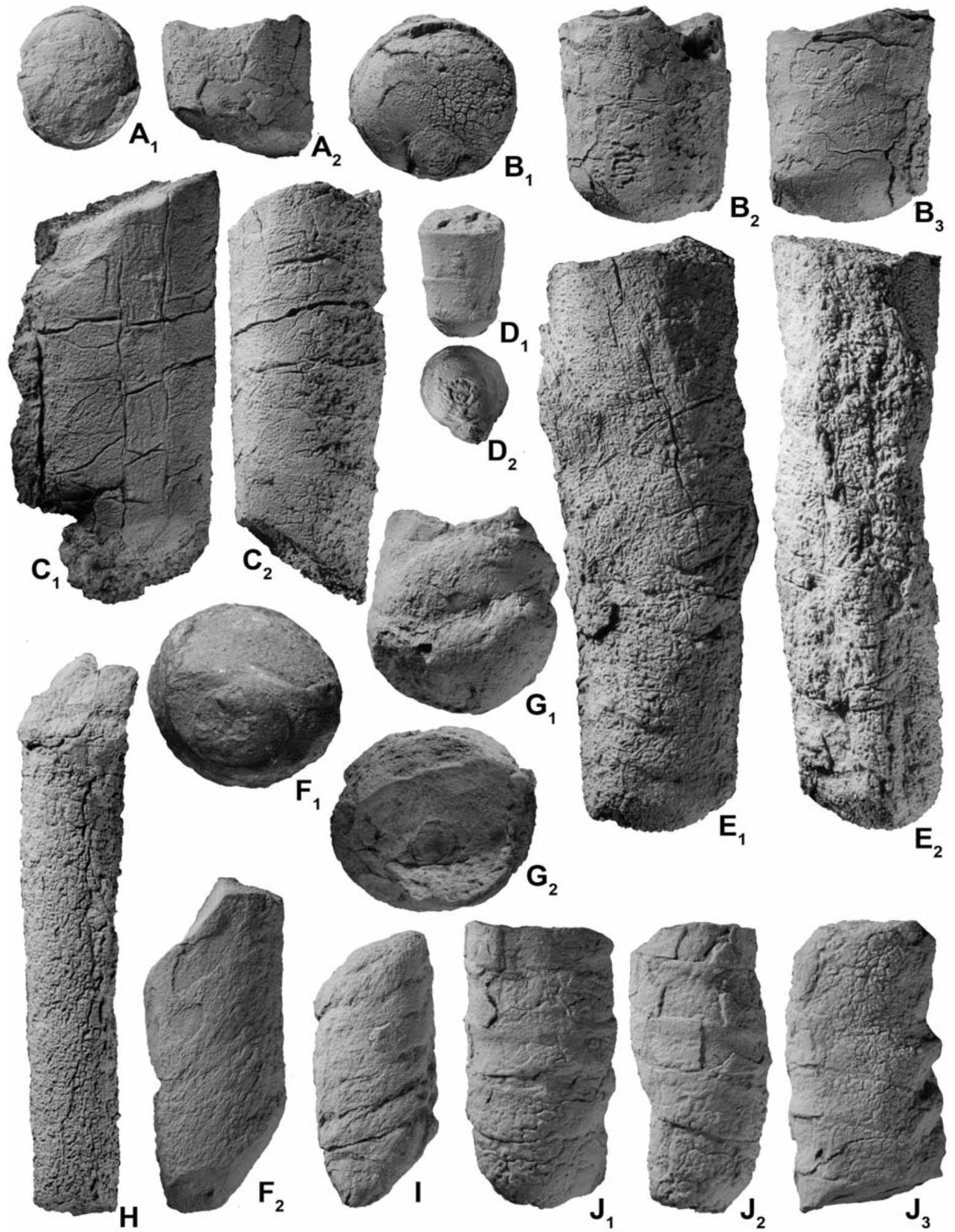

G1, G2 - NMW2014.6G.15, dorsal and adoral views of phragmocone showing a large subcentral phragmocone, $\times 1.88$. H - Suecoceras? sp. indet.; NMW2014.6G.20, slender and corroded siphuncle, $\times 1.41 . \mathrm{F}_{1}, \mathrm{~F}_{2}-$ Suecoceras sp. A; NMW2014.6G.10, apical view of phragmocone showing ventrally positioned siphuncle; $x$ 1.8, lateral view of phragmocone (venter on left), × 1.41. I - Eosomichelinoceras? sp.; NMW2104.6G.12, lateral view of slightly deformed phragmocone showing sutures (venter on left), $\times 1.88 . \mathrm{J}_{1}-\mathrm{J}_{3}$ - Dideroceras? sp.; NMW2014.6G.11, dorsal, lateral (venter on left) and ventral views of 


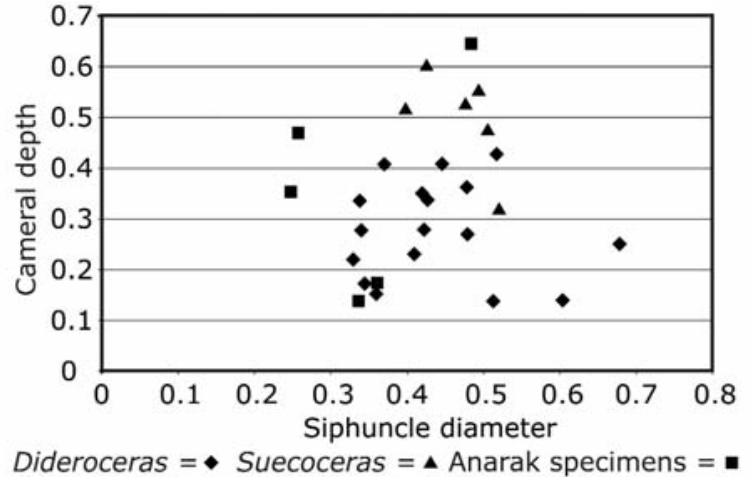

Text-fig. 11. Plot of cameral depth versus relative siphuncle diameter for several taxa assigned to Dideroceras and Suecoceras (sources Flower, 1964; Balashov, 1968) showing the two genera occupying different areas of the field but with some overlap and little separation. The filled squares represent specimens described here that either plot with Suecoceras or with Dideroceras (D. sp. 1) or close to Dideroceras (D. sp. 2)

\section{Genus Suecoceras Holm, 1896}

TYPE SPECIES: By original designation; Endoceras barrandei Dewitz, 1880, from the early Sandbian Dalby Limestone (Kukruse Stage and Idavere Substage) of the Sijlan District, Sweden.

REMARKS: Although Holm diagnosed Suecoceras on the basis of the swollen apical portion of the phragmocone and siphuncle, Flower observed that the additional taxa assigned to the genus by Balashov (1968), despite not preserving the inflated portion of the phragmocone, were reasonably assigned to Suecoceras on the basis of the slender tubular conchs, broad siphuncle and deep camerae. To some extent this is borne out by comparison of the siphuncle diameter and cameral depth with those of Dideroceras but the difference is gradational rather than discrete. Teichert (1964, K178) noted that the endocones of Suecoceras were extremely long and slender, whilst the septal necks are holochoanitic to slightly macrochoanitic. This seems to be confirmed in those specimens assigned to the genus and illustrated by Balashov (1968).

Suecoceras? sp. A.

(Text-figs 10F; 13F, L; 14H)

MATERIAL: NMW2014.6G.10, from sample 'F'.

DESCRIPTION: This specimen consists of a worn portion of phragmocone $42 \mathrm{~mm}$ long and $17 \mathrm{~mm}$ in diameter that may be slightly sheared and some elements of the conch have been subjected to pressure so- lution. The septa, seen only in the dorsal half of the phragmocone, show a curvature approaching that of an arctangent with an apparent overall depth from the dorsal margin of the phragmocone to the septal neck equivalent to $76 \%$ that of the diameter of the phragmocone. The distance between the septa is $64 \%$ that of the phragmocone diameter. The siphuncle is marginal and almost in contact with the ventral wall of the phragmocone. Its diameter is $48 \%$ that of the phragmocone. Although poorly preserved, the septal necks are considered to be holochoanitic rather than macrochoanitic as there is no evidence of the thickening of the wall of the siphuncle apically of the septal necks, and there appears to be a slight gap between the distal end of one septal neck and the septal foramen associated with the next siphuncular segment.

Endosiphuncular deposits are evident in this specimen, and although it is unclear whether an endosiphocone is present as it is difficult to interpret some of the fabrics within the siphuncle, it is clear from the contrast between the endosiphuncular deposits and the probable endosiphocone that the expansion rate of the endocones lies in the region of $5 \mathrm{de}-$ grees, making them exceptionally long; possibly as much as $55 \mathrm{~mm}$. In transverse section two endosiphoblades are visible. These are approximately $180 \mathrm{de}-$ grees apart and lie at 45 degrees to the dorsoventral plane of the phragmocone.

REMARKS: The relatively deep camerae and large siphuncle combined with the length of the septal necks and the long endosiphocones indicate that this specimen is best assigned to Suecoceras. It is difficult to assign this specimen to a particular species because of the probable overlaps between species of Suecoceras. The genus would benefit from a substantial revision.

Suecoceras? sp. indet. (Text-fig. 10H)

MATERIAL: NMW2014.6G.20, from sample 'F'.

DESCRIPTION: This specimen consists of a corroded piece of siphuncle $71 \mathrm{~mm}$ long, increasing in diameter from $11.4 \mathrm{~mm}$ to $12.7 \mathrm{~mm}$ over $46 \mathrm{~mm}$ giving a rate of expansion of 1.6 degrees. The cross-section is slightly depressed with an apical dorsoventral diameter of 10.4 $\mathrm{mm}$ and lateral diameter of $11.8 \mathrm{~mm}$. Nothing is seen of the septal necks or the connecting rings. As with NMW2014.6G.11 (above), the endosiphuncle is likely to consist of recrystallised endosiphuncular deposits.

REMARKS: Although corroded, the slender nature 
of this long fragment of siphuncle is suggestive of Suecoceras.

Subclass Orthoceratoidea McCoy, 1844

Order Orthocerida Kuhn, 1940

Family Baltoceratidae Kobayashi, 1935

Genus Eosomichelinoceras Chen, 1974

TYPE SPECIES: Eosomichelinoceras huananense Chen, 1974, from the Middle Ordovician of Southwest China.

REMARKS: Kröger et al. (2007) discussed the problems surrounding Chen's (Chen 1974) description of the genus, noting the brevity of the description and the referral to an original proposal of the genus and more extensive description in a paper published in 1964. This paper has not been found, and subsequent workers have referred to the genus as Eosomichelinoceras J. -Y. Chen, 1974. Based on the specimens figured by Chen (1974, pl. 61, figs 1-3), Eosomichelinoceras is a longiconic orthocone with a small apical angle, deep camerae $54-85 \%$ of the phragmocone diameter, a narrow siphuncle with a diameter $6 \%$ that of the phragmocone that lies $30 \%$ of the way across the phragmocone. The septal necks are short and orthochoanitic, whilst the connecting ring is tubular. No cameral or endosiphuncular deposits are known. Externally, the conch sculpture consists of transverse striae with a density of 5 per $\mathrm{mm}$, inclined at about 4 degrees to the normal of the conch axis.

\section{Eosomichelinoceras? sp.}

(Text-figs 10I; 13J; 14D)

\section{MATERIAL: NMW2014.6G.12, from sample 'F'.}

DESCRIPTION: Externally this specimen consists of a worn and possibly slightly sheared portion of phragmocone $26 \mathrm{~mm}$ long and $12 \mathrm{~mm}$ in diameter. The sutures, septal surfaces and traces of the siphuncle are visible on the surface of the internal mould. In dorsoventral sagittal section, the depth of the septa is estimated to be $21 \%$ of the phragmocone diameter, whilst the depth of the camerae is $25 \%$ of the phragmocone diameter. The diameter of the siphuncle at the septal foramen is $9 \%$ of the diameter of the phragmocone and lies about $22 \%$ of the way across the phragmocone from the conch wall. The septal necks are orthochoanitic and $0.5 \mathrm{~mm}$ in length. The connecting rings are not preserved. No endosiphuncular or cameral deposits are evident.
REMARKS: This specimen differs from Eosomichelinoceras huananense in possessing substantially shallower camerae. This is also the case when this specimen is compared with the second specimen illustrated by Chen (1974, pl. 61, fig. 3); of a similar diameter to the specimen under discussion. In comparison with $E$. baldisii Kröger, 2007, from the early Darriwilian, San Juan Formation of the Precordillera, Argentina, the camerae are of a similar depth, but the siphuncle is broader and lies nearer to the conch axis, whilst the siphuncular segments are slightly inflated on the side nearest the phragmocone wall.

Family Sactorthoceratidae Flower, 1946

REMARKS: Although the family was diagnosed as possessing endosiphuncular and cameral deposits by Kröger et al. (2007), such structures are only known with certainty from Murrayoceras Foerste, Cartersoceras Flower and possibly Leptoplatophrenoceras Zou and Chen. They appear to be unknown in Sactorthoceras and the other genera assigned to the family by Kröger et al. (2007). Thus Murrayoceras and Cartersoceras, previously assigned to the Baltoceratidae by Flower 1964, but assigned to the Sactorthoceratidae by Kröger et al. (2007) may not belong in this family, despite the apparent similarity indicated by the possession of a relatively thick connecting ring.

Genus Wolungoceras Kobayashi, 1931

TYPE SPECIES: By original designation; Wolungoceras foersteri Kobayashi, 1931, p. 166, pl. 18, figs $1 \mathrm{a}-\mathrm{c}$, from the Wolung Limestone of the Niuxintai Basin, Liaoning Province, China.

REMARKS: Wolungoceras is a poorly known orthoconic longicone known from a small number of specimens. It possesses a broad, subcentral siphuncle with orthochoanitic septal necks, thick connecting rings and lacks either cameral or endosiphuncular deposits. Poor knowledge of the genus has probably contributed to its assignment to the Baltoceratidae by Flower (1964), the Troedssonellidae (Sweet, 1964) and the Sactorthoceratidae (Kröger et al. 2007). Kröger (in Kröger et al. 2007) assigned the genus (as '?Wolungoceras') to the Sactorthoceratidae on the grounds of the relatively thick connecting rings, which he considered characteristic of the family. The relatively broad siphuncle distinguishes the genus from other members of the family, and might indicate that it represents a member of a stem group to the Sactorthoceratidae. Although Kobayashi (1931, p. 166) noted 
that the structure of the siphuncle was the same as that of Ellesmeroceras Foerste, the illustrations of the type species are not sufficiently clear to be able to elucidate the structure of the siphuncle. His interpretation (Kobayashi 1931, pl. 18, fig. 1b), suggests that the connecting rings were slightly expanded with the convex surface facing into the lumen of the siphuncle; unlike members of the Ellesmeroceratidae. Despite the impression of relatively shallow camerae given by Kobayashi's illustrations, his description indicates a cameral depth about $40 \%$ of the phragmocone diameter, and a siphuncle diameter about $30 \%$ that of the phragmocone diameter.

\section{Wolungoceras? sp. (Text-figs 10D, G; 13B; 14G)}

MATERIAL: NMW2014.6G.3, 15, from sample 'F'.

DESCRIPTION: NMW2014.6G.15 consists of a short length $(17 \mathrm{~mm})$ of phragmocone $18 \mathrm{~mm}$ in diameter and formed of three camerae. Although the surface of the phragmocone is worn, the outline of a relatively large subcentral siphuncle is visible on the adoral and adapical septa. In dorsoventral sagittal section, the depth of the septa is $25 \%$ of the diameter of the phragmocone. Of the three camerae preserved, one is $26 \%$, and the other two about $21 \%$ of the phragmocone diameter in depth. The centre of the siphuncle lies $34 \%$ of the way across the phragmocone from the conch wall, and has a diameter $20.5 \%$ that of the conch, so that wall of the siphuncle lies $4.2 \mathrm{~mm}$ from the conch wall. The siphuncle is distinctly tubular in outline and possesses loxochoanitic to orthochoanitic septal necks $0.7 \mathrm{~mm}$ long. The connecting rings are approximately $0.2 \mathrm{~mm}$ in thickness, and appear to be uniform in thickness throughout their length. No endosiphuncular or cameral deposits are visible.

NMW2014.6G.3 is a smaller piece of phragmocone, $14 \mathrm{~mm}$ long with a diameter of $7.7 \mathrm{~mm}$ and an estimated apical angle of 9 degrees. The septa appear to be shallower (18\% of the phragmocone diameter), although this may reflect the difficulty of obtaining this measurement for the specimen. Cameral depth is greater at $55 \%$ of the phragmocone diameter, whilst the siphuncle is larger $31 \%$ of the phragmocone diameter) and more centrally positioned ( $45 \%$ of the distance across the diameter of the phragmocone. This specimen has not been sectioned, but no evidence of the presence of endosiphuncular or cameral deposits is visible on the surface of the internal mould.

REMARKS: In their overall morphology (relative si- phuncle diameter and cameral depth), these two extremely fragmentary specimens are not dissimilar to $\mathrm{Wol}$ ungoceras, although the camerae are deeper in NMW2014.6G.3. Perhaps the main difference lies in the more tubular form of the connecting rings as seen in NMW2104.6G.15. The fauna reported from the Wolung Limestone by Kobayashi consists largely of endocerids and piloceratids, including Piloceras wolungense Kobayashi, later assigned to Manchuroceras by Kobayashi (1937), and suggesting a Floian date for the Wolung Limestone. W. valcourense Flower, from the Fort Cassin Formation of New York (Flower 1964) is similar in age, whilst the specimens described above are substantially younger, giving further reason to assign these specimens to Wolungoceras with a degree of uncertainty.

Genus Wennanoceras Chen, 1976

TYPE SPECIES: By original designation; Wennanoceras costatum Chen, 1976, p. 67, from the Middle Ordovician Majiagou Formation, of Shandong, North China.

REMARKS: Wennanoceras is a slender, faintly cyrtoconic, annulate orthocone, with a narrow, central and tubular siphuncle possessing orthochoanitic septal necks. The surface of the conch possesses prominent and angular annulations. No endosiphuncular or cameral deposits are known. Yun (2011) described several species of Wennanoceras from the Jigunsan Formation of South Korea. These include specimens assigned to the type species and closely related taxa, as well as species originally assigned to Protocycloceras and Cycloceras by Kobayashi $(1927,1934)$. If representing a single genus, then apart from variation in the apical angle, and minor variation in the position and relative diameter of the siphuncle, the main intrageneric variation appears to involve the relative number of camerae that occur within a wavelength of an annulation; being as little as one per annulation in $W$. costatum and $W$. xizangense Chen, up to two in W. chikunense (Kobayashi, 1927), and as great as three in $W$. sp. B. (Yun, 2011, pl. 11, fig 4). Yun (2011) assigned Wennanoceras to the Leurocycloceratidae, although Kröger et al. (2007) placed the genus in the Sactorthoceratidae on the grounds of the relatively greater thickness of the connecting rings compared with other members of the Orthocerida.

Wennanoceras sp.

(Text-figs 12A, B; E, K; 14F)

MATERIAL: NMW2014.6G.1,13, from sample 'F'. 
DESCRIPTION: The phragmocone represented by NMW2014.6G1 consists of a $60 \mathrm{~mm}$ long portion of a weakly cyrtoconic longicone with a slightly depressed cross section decreasing in the ratio of the lateral to dorsoventral diameter from 1.2 apically to 1.1 adorally. The apical angle in the dorsoventral plane is 7.5 degrees. The surface of the conch shows annulations about $4 \mathrm{~mm}$ apart and $0.35 \mathrm{~mm}$ in amplitude. Both the culminations and the troughs of the annulations are gently rounded and the sutures appear to be aligned with the troughs. Septal depth is about $30 \%$ of the diameter of the phragmocone, whilst cameral depth is around $21 \%$ of the phragmocone diameter. At $3.5 \mathrm{~mm}$ in diameter, the relative diameter of the siphuncle is $21 \%$ that of the phragmocone, whilst its centre is positioned $45 \%$ of the way across the dorsoventral diameter of the conch from the side with a concave curvature. The siphuncle is tubular with no indication of any constriction at the septal foraminae. Due to the presence of a recrystallised isopachous cement within the camerae and on the surface of the lumen of the siphuncle it is difficult to be confident with regard to the form of the septal necks. They appear to be loxochoanitic to weakly loxochoanitic, and where discernable, are $0.5 \mathrm{~mm}$ in length whilst the connecting rings are $0.18 \mathrm{~mm}$ in thickness. No endosiphuncular or cameral deposits are evident.

The second specimen, NMW2014.6G.13 is a heavily corroded portion of phragmocone $20 \mathrm{~mm}$ long. The diameter of this specimen is $11.7 \mathrm{~mm}$, but this is likely to be an underestimate because of the loss of material
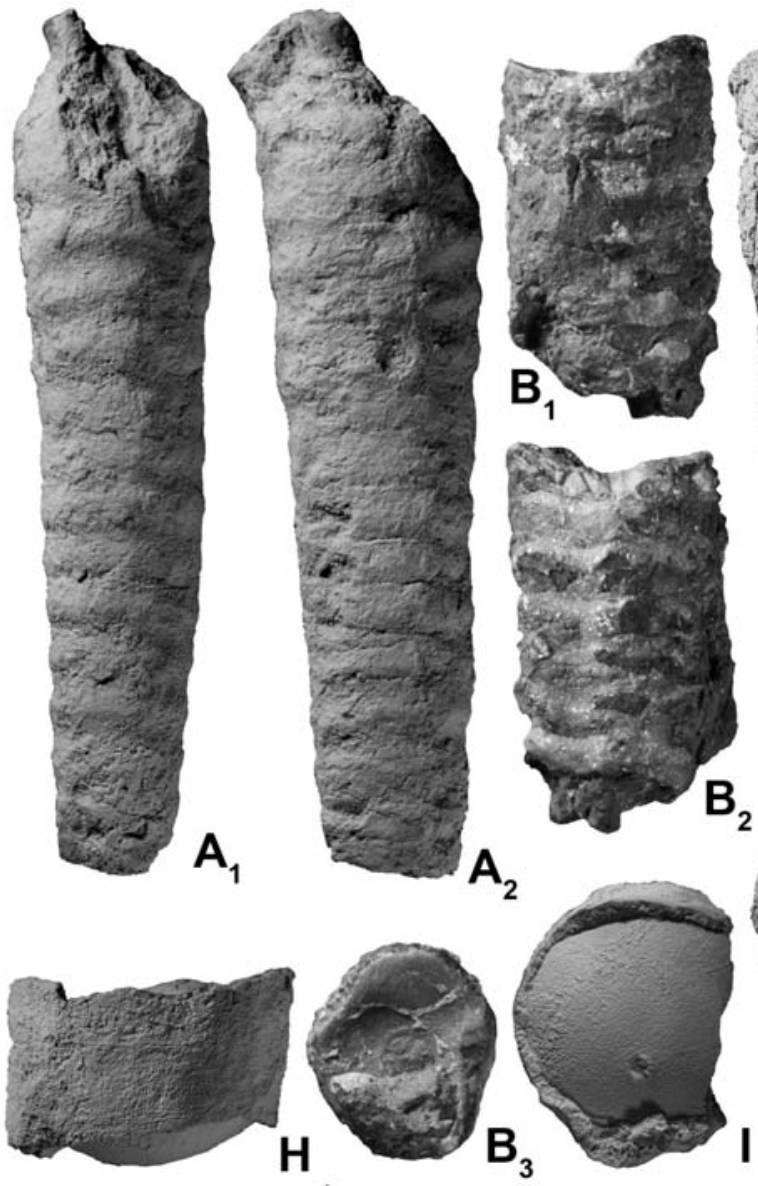

$\mathrm{H}$

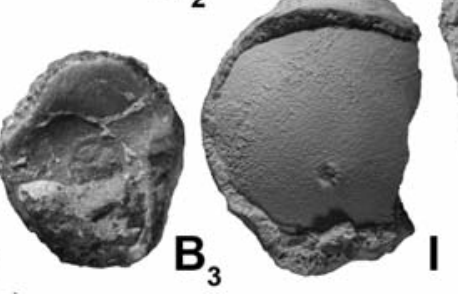

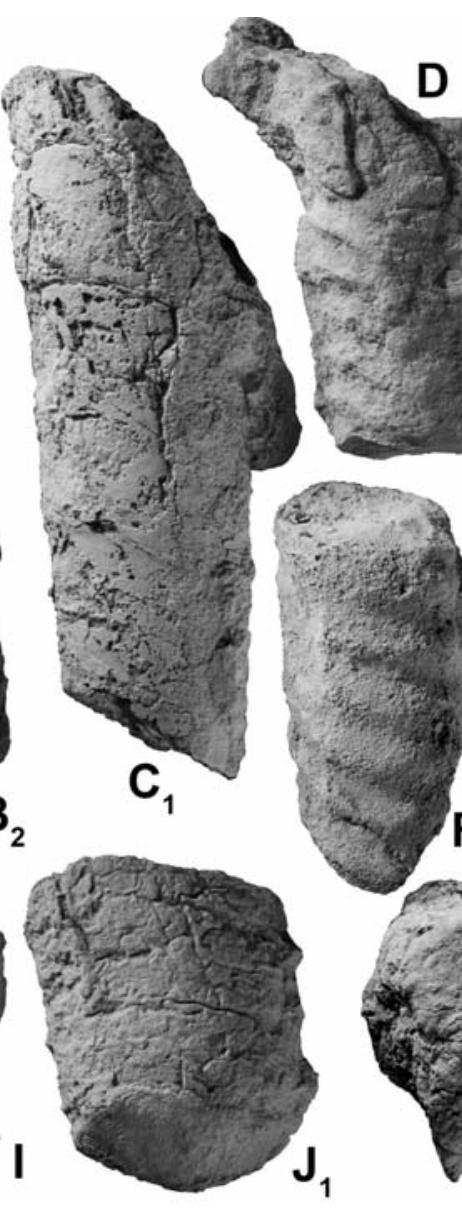
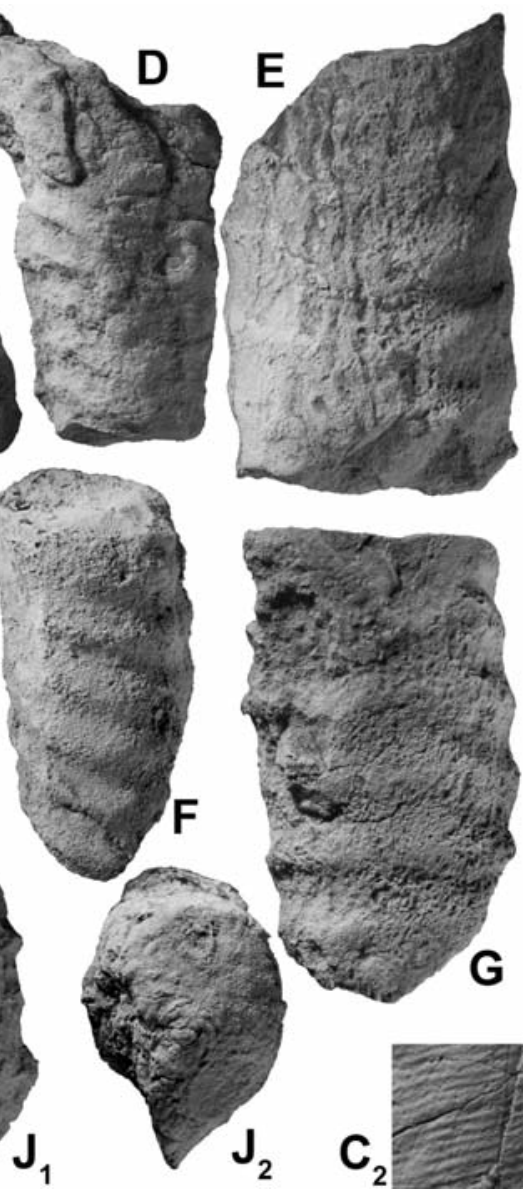

Text-fig. 12. Cephalopods from the Chahgonbad Formation, sample 'F'. A, B - Wennanoceras? sp.; $\mathrm{A}_{1}, \mathrm{~A}_{2}-\mathrm{NMW} 2014.6 \mathrm{G} .1$, lateral (venter on left) and ventral views of phragmocone showing siphuncle protruding from adoral surface, $\times 1.41 ; \mathrm{B}_{1}-\mathrm{B}_{3}-\mathrm{NMW} 2014.6 \mathrm{G} .13$, lateral views (venter on right and left respectively) and adoral view of corroded phragmocone showing the septal foramen (venter down), $\times 1.88 . \mathrm{C}_{1}, \mathrm{C}_{2}-$ Geisonoceratid genus and sp. indet., NMW2014.6G.7, phragmocone (orientation unknown) showing faint traces of inclined sutures, $\times 1.18$, same specimen, detail of conch sculpture, $\times 5.64$. D-G - NMW2014.6G.8. Annulate cephalopod, order, family and genus indet., D - phragmocone or body-chamber (orientation unknown, $\times 1.41$; E - NMW2014.6G.14, phragmocone or body-chamber showing sinus formed by annulations and longitudinal lirae, $\times 1.41$; F - NMW2014.6G.17, phragmocone or body-chamber showing strongly inclined annulations, $\times 1.41$; G - NMW2014.6G.18, phragmocone or body-chamber with almost directly transverse annulations, $\times 1.41$. H, I, J - Allumettoceras? sp.; H - NMW2014.6G.19, lateral view of small portion of phragmocone (venter on left), $\times 1.41$; I - same specimen, apical surface showing subcentral septal foramen, $\times 1.41 ; \mathrm{J}_{1}, \mathrm{~J}_{2}-\mathrm{NMW} 2014.6 \mathrm{G} .4$, lateral and apical views of phragmocone showing septal foramen, $\times 1.41$ 
through weathering. Assuming this to be the case, the depth of septa is $25 \%$ that of the phragmocone, whilst cameral depth is $21 \%$. The siphuncle diameter is $21 \%$ that of the phragmocone and its centre is positioned $45 \%$ of the way across the diameter of the phragmocone. The siphuncle appears to be tubular throughout its length. The orientation of the sagittal section is not entirely clear, but the septal necks appear to differ slightly on either side of the siphuncle. On the left side, the septal necks lie between loxochoanitic and orthochoanitic, and $0.53 \mathrm{~mm}$ long, whereas on the right side they are orthochoanitic and $0.3 \mathrm{~mm}$ long. The connecting rings are between 0.17 and $0.2 \mathrm{~mm}$ in thickness. No endosiphuncular or cameral deposits are evident.

REMARKS: The corrosion of the surface of the specimens described above makes them difficult to compare with $W$. costatum in terms of the angularity of the culminations of the annulations. However, the internal morphology of these phragmocones is very similar to that of $W$. costatum and $W$. xizangense, and apparently differs only in the more eccentric position and larger relative diameter of the siphuncle. Neither of these variations in character may be particularly significant. Given the range of variation in the species referred to above, the specimens described here lie well within the morphological range of the type and closely related species of Wennanoceras.

Family Geisonoceratidae Zhuravleva, 1959

Geisonoceratid genus and sp. indet. (Text-fig. 12C)

\section{MATERIAL: NMW2014.6G.7, from sample 'F'.}

DESCRIPTION: This specimen consists of a portion of phragmocone $62 \mathrm{~mm}$ long, increasing in diameter from 16.3 to $23.5 \mathrm{~mm}$ over a distance of $43 \mathrm{~mm}$, giving an apical angle of 9.5 degrees. The transverse cross-section of the conch is appears to be very slightly compressed (ratio of assumed lateral to assumed dorsoventral diameter $=0.94)$. Sutures are visible. These are straight, but inclined to the normal of the conch axis by about 15 degrees. Septal depth is $33 \%$ that of the phragmocone diameter and the cameral depth is $51 \%$. Although the septa are sufficiently well preserved to ascertain septal and cameral depth, they are otherwise largely broken and disrupted and the siphuncle cannot be located. The conch sculpture is preserved and consists of transverse striae that, as with the sutures, are inclined to the normal of the conch axis at about 15 degrees. The striae consist of slightly raised threads $0.1 \mathrm{~mm}$ wide combined with slightly concave intervening spaces. The density of the striae ranges from 3 to 5 per $\mathrm{mm}$.

REMARKS: Since nothing is known of the size, position and structure of the siphuncle, other than it is unlikely to be marginal, the correct taxonomic assignment of this specimen is very speculative. It has not been assigned to the Orthoceratidae as the apical angle is substantially higher than that seen in genera such as Orthoceras Brugière or Michelinoceras Foerste, where based on the type species, it may be as little as $2-3$ degrees. A similarly inclined conch sculpture to the specimen under discussion may be observed in Geisonoceras Hyatt and Virgoceras Flower where the apical angle lies at 4-5 degrees. Arionoceras Barskov possesses a similar apical angle, but the camerae are shallower whilst the conch sculpture, where present is directly transverse. This specimen is included here because it is distinct from other members of the Anarak cephalopod fauna. Additional, better-preserved material, if discovered, may better elucidate the taxonomic position of this specimen.

Family Proteoceratidae Flower, 1962

Genus Allumettoceras Foerste, 1926

TYPE SPECIES: By original designation; Tripteroceras pauquettense Foerste, from the Leray-Rockland beds of the Ottawa Formation, Paquette Rapids, Ottawa River, Canada.

Allumettoceras? sp.

(Text-figs 12H-J; 13G, I; 14E)

MATERIAL: NMW2014.6G.4, 19, from sample ' $F$ '.

DESCRIPTION: NMW2014.6G.19 is a short length (14 mm) of phragmocone consisting of two camerae, that increases in diameter from 19.54 to $20.8 \mathrm{~mm}$ in a distance of $11.6 \mathrm{~mm}$, indicating an apical angle of around 6 degrees. Although part of one of the lateral margins of the specimen is missing the general profile of the trans-

Text-fig. 13. Cephalopods from the Chahgonbad Formation, sample 'F'. A, D - Dideroceras? sp. 1; $\mathrm{A}_{1}, \mathrm{~A}_{2}-\mathrm{NMW} 2014.6 \mathrm{G} .2$, sagittal dorsoventral and transverse sections through phragmocone, the latter showing section across circular endosiphotube, $\times 2.82$; D - NMW2014.6G.16, sagittal dorsoventral section through phragmocone, $\times 2.35$. C, $\mathrm{H}-$ Dideroceras? sp. 2.; $\mathrm{C}_{1}, \mathrm{C}_{2}-$ NMW2014.6G.5, sagittal dorsoventral and transverse sections through phragmocone, $\times 1.88$; H - NMW2014.6G.6, transverse section of phragmocone, x 1.88. B - Wolungoceras? sp., NMW2014.6G.15, dorsoventral sagittal section of phragmocone, venter on left, $\times 2.82$. E, K - Wennanoceras? sp.; E1, E2 - NMW2014.6G.1, transverse and slightly oblique lateral sagittal sections through phragmocone, $\times 2.36$ 
ORDOVICIAN OF CENTRAL IRAN

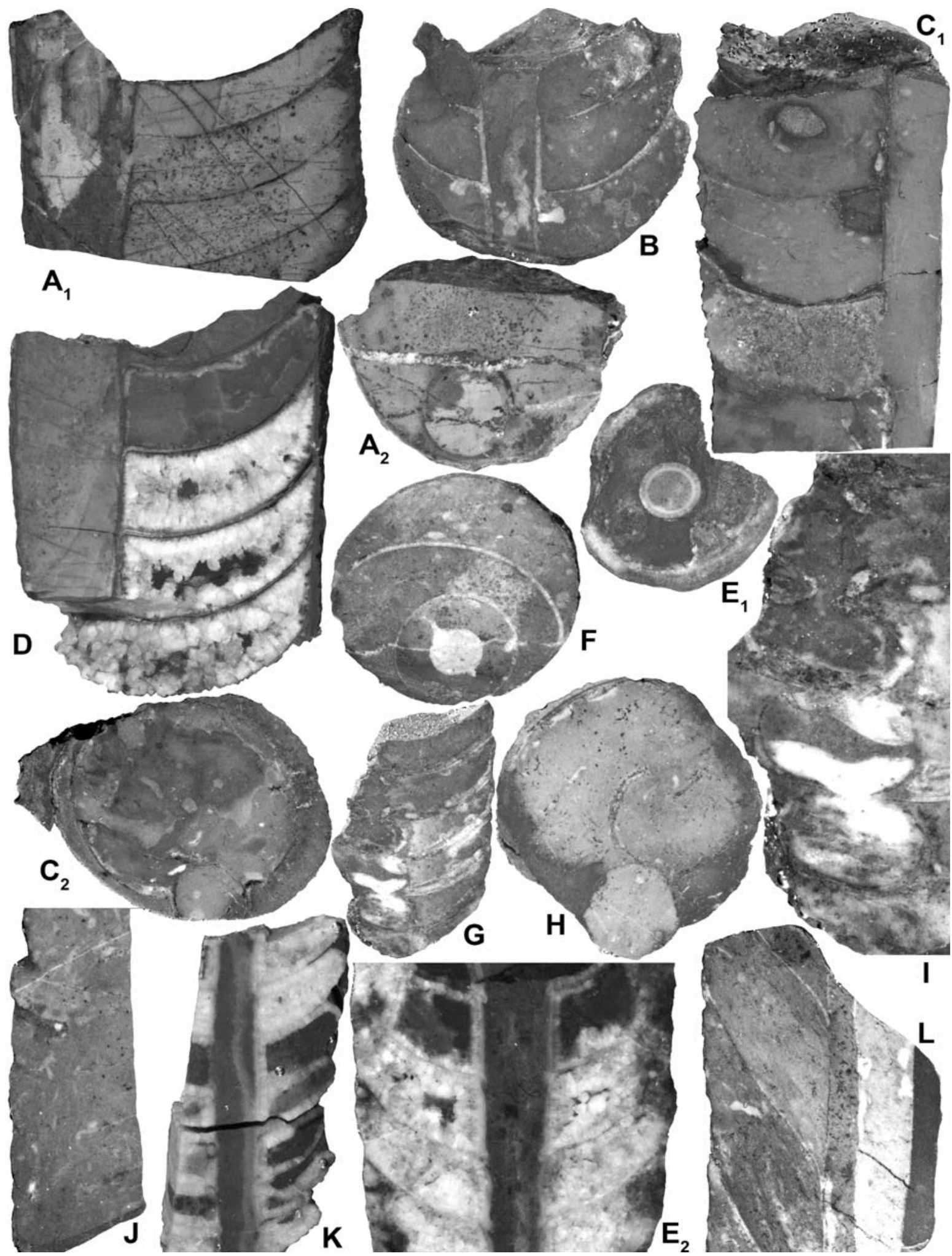

and x 4 respectively; K - NMW2014.6G.13, sagittal section through phragmocone. F, L - Suecoceras? sp.; F - NMW2014.6G.10, transverse section showing endosiphuncular deposits apparently differentiated into dark and light coloured material with the trace of a pair of simple endosiphoblades visible; $\mathrm{L}$ - dorsoventral sagittal section showing the very long endosiphocones; $\times 2.36$. G, I - Allumettoceras? sp.; G - dorsoventral sagittal section through phragmocone showing cameral deposits and general nature of siphuncle, $\times 1.88$; I - NMW2014.6G.4, details of siphuncle showing distribution of endosiphuncular deposits, $\times 3.29$. J - Eosomichelinoceras? sp., NMW2014.6G.12, dorsoventral sagittal section of phragmocone showing septa and poorly preserved traces of septal foraminae, $\times 2.82$ 
verse section of the phragmocone suggests that it may be slightly depressed. The depth of the septa is $19.7 \%$ of the phragmocone diameter, and cameral depth is $22 \%$. Although the septal foramen is visible, the dorsoventral sagittal section of the phragmocone shows that the connecting rings have either been destroyed or entirely obscured by the coarsely crystalline fill of the camerae. The diameter of the septal foramen is estimated to be $7.5 \%$ that of the phragmocone and its centre lies $33 \%$ of the distance across the diameter of the phragmocone from the venter. No cameral deposits are present.

NMW2014.6G.4 consists of a portion of phragmocone $25.5 \mathrm{~mm}$ long with the presumed ventral side missing. Septal depth is $19.2 \%$ of the phragmocone diameter and cameral depth is $3.6 \mathrm{~mm}$ or $20.5 \%$. The septal foramen is $1.9 \mathrm{~mm}$ or $11 \%$ of the phragmocone diameter, and the position of its centre is estimated to be $3.7 \mathrm{~mm}$ or $27 \%$ of the distance across the diameter of the phragmocone from the presumed venter. At its maximum diameter, the diameter of the siphuncular segment is $6.7 \mathrm{~mm}$ or $38.5 \%$ of the phragmocone diameter, and 3.5 times greater than the diameter of the septal foramen, giving the siphuncular segments a nummuloid shape. The septal necks appear to be cyrtochoanitic and recumbent. Endosiphuncular deposits are present, but are too strongly recrystallised to make out any fine structures. They appear to take the form of massive endosiphuncular annuli at the septal foraminae and may extend onto the connecting ring as parietal deposits. The septa are covered with evenly layered episeptal cameral deposits that extend onto the mural surfaces of the camerae. Substantially thinner and more patchily distributed hyposeptal deposits are also present.

REMARKS: Given the extremely fragmentary nature of these specimens, their assignment to Allumettoceras is very tentative. Comparison with other species of $\mathrm{Al}$ lumettoceras where endosiphuncular and cameral deposits are known (Evans 1994) may suggest a degree of similarity to A. courtownense Evans in the possession of markedly nummeloidal siphuncular segments. However, the transverse section of this species as interpreted (Evans 1994, fig. 7c) is markedly different. Although the state of preservation of the endosiphuncular deposits in NMW2014.6G.4 are insufficient to distinguish detailed fabrics, the general form at the adoral end of the si-
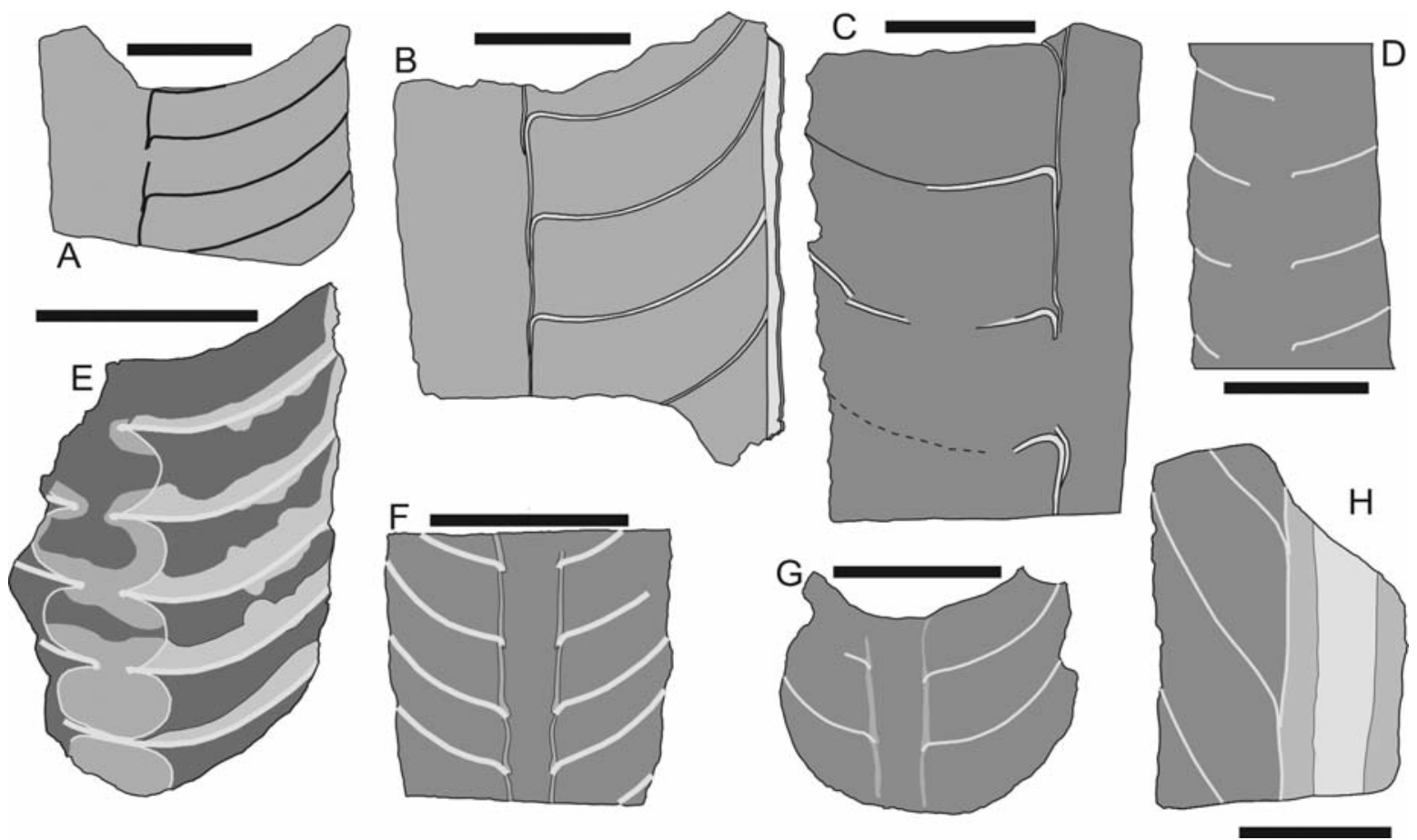

Text-fig. 14. Cephalopods from the Chahgonbad Formation, sample 'F'. Interpretative diagrams of sectioned phragmocones illustrated in Text-fig. 13. A, B - Dideroceras sp. 1.; A - NMW2014.6G.2, showing macrochoanitic septal necks, connecting rings not clearly distinguished, B - NMW2014.6G.16, macrochoanitic necks visible, connecting rings are not possible to distinguish. C - Dideroceras sp. 2., NMW2014.6G.5, showing long camerae and macrochoanitic septal necks, but connecting rings cannot be distinguished. D - Eosomichelinoceras? sp., NMW2014.6G.12, showing septa and traces of orthochoanitic septal necks. E - Allumettoceras? sp., NMW2014.6G.4, showing cyrtochoanitic septal necks, hyposeptal and episeptal cameral deposits, and endosiphuncular deposits developed as annuli at the septal necks and as probable parietal deposits on the connecting rings. F - Wennanoceras? sp., NMW2014.6G.1, showing the loxochoanitic to weakly orthochoanitic septal necks and connecting rings. G - Wolungoceras? sp., NMW2014.6G.15, with loxochoanitic to weakly orthochoanitic septal necks and relatively thick connecting rings.

H - Suecoceras? sp., NMW2014.6G.12, showing macrochoanitic septal necks and very long endocones. All scale bars are $10 \mathrm{~mm}$ except (d) which is $5 \mathrm{~mm}$ 
phuncle suggests that they originated at the septal necks and grew adorally and adapically, ultimately forming a parietal lining on the mid-portions of the segments. By comparison, new material of $A$. oneratum Evans (Evans in prep.) shows that the endosiphuncular deposits originate as annuli at the septal foraminae and then grow adorally into the next segment. These Anarak specimens also bear some resemblance to Pseudowutinoceras Chen and Zou in the shape and position of the siphuncle, as well as the distribution of the endosiphuncular deposits. However, the diagnosis of the genus (Chen and Zou 1984, p. 84) as well as illustrations in the same work fail to demonstrate the presence of the cameral deposits seen in NMW2014.6G.4.

Annulate cephalopod, Order, family and genus indet. (Text-fig. 12D-G).

MATERIAL: NMW2014.6G. 8, 14, 17, 18 from sample 'F'.

DESCRIPTION: All four specimens consist of internal moulds that lack any evidence of the presence of septa or a siphuncle, and may consist of body-chambers. These fragments range from $30 \mathrm{~mm}$ to $50 \mathrm{~mm}$ in length, and $14 \mathrm{~mm}$ to $20 \mathrm{~mm}$ in diameter. The apical angle is only possible to estimate in NMW2014.6G.8 where it is 4.5 degrees. The distance between annulations increases from $3.8 \mathrm{~mm}$ to $6.1 \mathrm{~mm}$ with the increase in diameter of the conchs, whilst the amplitude lies between $0.8 \mathrm{~mm}$ and $1.2 \mathrm{~mm}$. The culminations of the annulations appear to be relatively angular in the specimens of a smaller diameter, but become more rounded at larger diameters. The annulations are inclined to the normal of the conch axis in three of the specimens by about 14 degrees (NMW2014.6G.8, 17 ), producing an apparent sinus on one side of the conch. The sinus is particularly marked in NMW2014.6G.8, where it exhibits a strong apical deflection. Small areas of shell are preserved in NMW2014.6G.14 these take the form of poorly preserved longitudinal lirae about $1 \mathrm{~mm}$ apart and approximately $0.5 \mathrm{~mm}$ in width.

REMARKS: Since the septa and the siphuncle are not preserved in these specimens, it is not possible to assign this material to any particular taxonomic group. Potentially, these specimens might represent the more adoral portions of specimens of Wennanoceras. Equally, they may represent the remains of members of the endocerid family, Cyrtendoceratidae, known to occur in the Darriwilian of the Shirgesht Formation of the Derenjal Mountains and the Lashkarak Formation of the eastern Alborz (Evans et al., 2013). Without additional material the nature of this material is unlikely to be satisfactorily resolved, and it is included here for the sake of completeness.

\section{Tentaculitids (by M. Ghobadi Pour and L.E. Holmer)}

Order Tentaculitida Ljashenko, 1955

Family Costatulitidae Berger, 1982

Genus Costatulites Berger, 1982

TYPE SPECIES: By original designation; Costatulites homogenus Berger, 1982, Silurian, Llandovery, Khaastyr Formation, Moiero River, Central Siberia.

\section{Costatulites? sp.}

(Text-fig. 15A)

MATERIAL: 23 external moulds, including NMW 2012.7G. 179, 180; 198,199; 341-347 (Text-fig. 15A) from samples AF-7/0 and AF-7/1.

REMARKS: These specimens consist of small sized conchs, up to $8 \mathrm{~mm}$ long with, a proximal part expanding at $8^{\circ}$ and the distal part at $2-4^{\circ}$. They are ornamented with up to 30 almost symmetrical rings gradually increasing in size and spacing towards the aperture. Poorly preserved fine, regular lirae are present between the rings. The characters of the living-chamber and the septal region cannot be seen in the specimens studied; however, their proliferation on sandy substrate suggests that unlike cornulitids they were liberosessile, making their attribution to tentaculitids more likely. The undoubted Late Ordovician tentaculitide Costatulites kimi have been recently described from the Seyahou Fotmation (Katian) of the Faraghan Mountains in High Zagros, south-east Iran (Ghavidel-Syooki et al. 2015b), where it also inhabited the sandy seafloors of shoal complexes together with brachiopods characteristic for Svobodaina havliceki Association. Specimens from the Chahgonbad Formation are similar to Costatulites kimi in their characters of surface ornament and low proximal growth angle; however, their precise taxonomic attribution is questionable because of the inadequate preservation of conchs.

\section{Trilobites (by M. Ghobadi Pour)}

Family Calymenidae Milne Edwards, 1840

Subfamily Reedocalymeninae Hupé, 1955

Genus Vietnamia Kobayashi, 1960 
TYPE SPECIES: By original designation; Calymene douvillei Mansuy, 1908, Upper Ordovician, Na Mo Formation, Thai, Vietnam.

Vietnamia cf. teichmulleri (Hamman and Leone, 1997) (Text-fig. 15D)

MATERIAL: NMW 2012.7G.354.1, external mould of cranidium from sample AF- 7/2.
REMARKS: The single cranidium available for study is characterised by a broad, trapezoidal glabella about three-quarters as long as wide with a short, gently and evenly convex anterior glabellar margin, three pairs of glabellar lobes separated by prominent, subparallel glabellar furrows inclined posteriorly adaxially, and with an occipital ring delineated by a sharp occipital furrow, gently curved forwards medially. The preglabellar field is in-
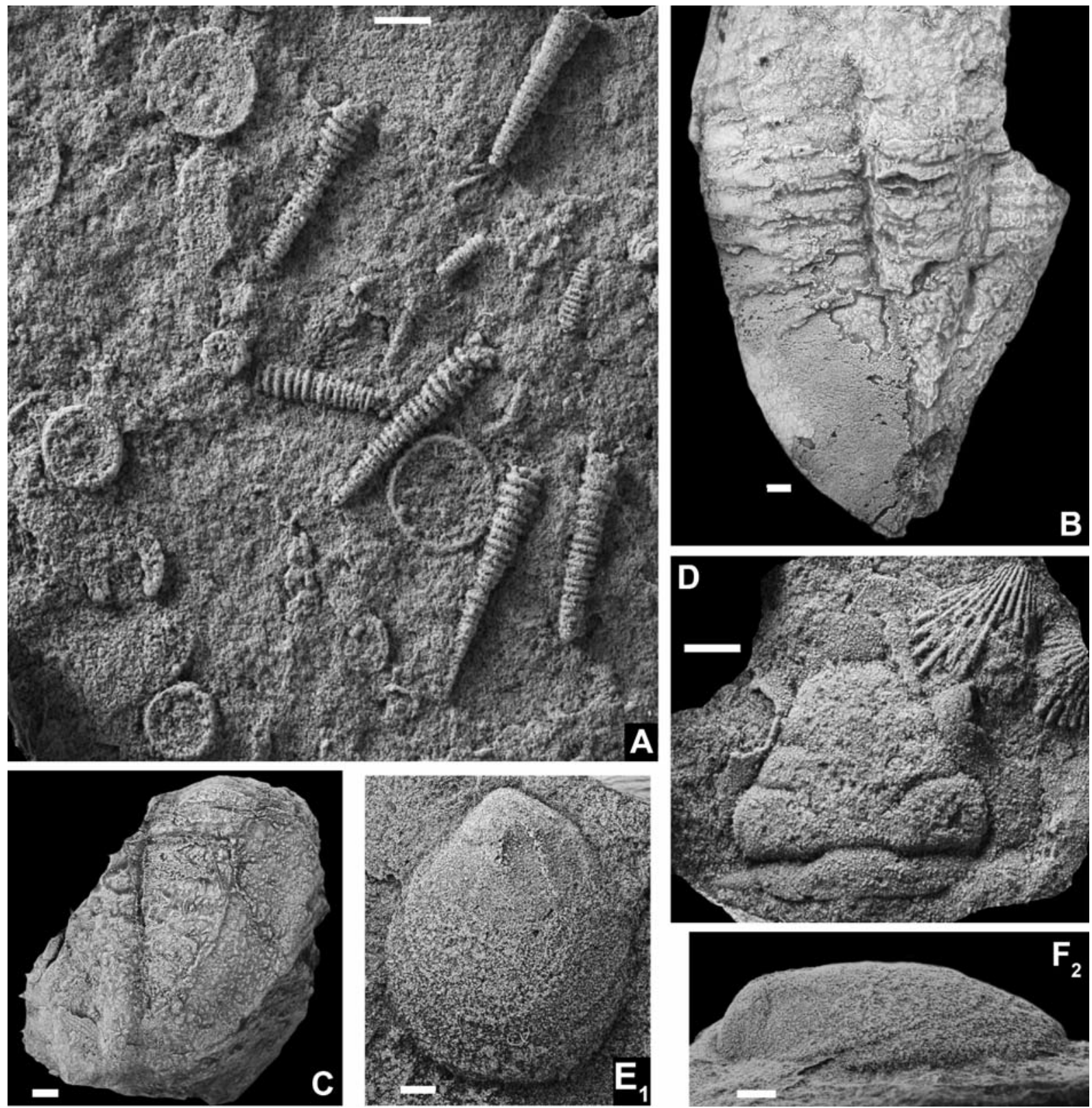

Text-fig. 15. Brachiopods, trilobites and tentculitids from Upper Ordovician (Katian) Chahgonbad Formation. A-Costatulites sp., sample AF-7/0, NMW 2012.7G.341347. B, C - Gen. et sp. indet. Asaphidae, sample 'F'; B - NMW 2012.7G.100, pygidium plus torax; C - NMW 2012.7G.101, pygidium. D - Vietnamia cf. teichmulleri (Hammann and Leone, 1997); NMW 2012.7G.354.1, latex cast of incomplete cranidium, and Rostricellula cf. ambigena Havliček, 1961, NMW 2012.7G.354.2, 3 , two ventral valves; latex cast from sample AF-7/2. $\mathrm{E}_{1}, \mathrm{E}_{2}$ - Hindella prima sp. nov., NMW 2012.7G.238, latex cast of ventral exterior, sample AF-8/2 
completely preserved, although a weakly defined anterior glabellar boss and a shallow anterior border furrow can be observed. In its cranidial morphology, and in particular, in having a broad, laterally expended L1, widening slightly outwards, and a convex lateral border; combined with the absence of the intermediate lobes, it resembles, and may be conspecific to Vietnamia teichmulleri (Hamman and Leone, 1997) from the Punta Serpeddi Formation (Katian) of Sardinia (Hammann and Leone, 1997). This species has been reported more recently from the upper part of the Rann Formation of the northern Oman Mountains (Fortey et al. 2011). As noted by Fortey in Fortey et al. (2011), Vietnamia teichmulleri has a small median depression in front of the glabella. This has not been observed in the specimen from Anarak.

Another similar species is Vietnamia pamirica (Balashova, 1966) from the Upper Ordovician (Katian) Kyzyndy Formation of eastern Pamir, which was also described and illustrated earlier by Weber (1948) as 'Calimene aff. birmanica Reed, 1906'. It differs from Vietnamia teichmulleri mainly in having more prominent glabellar furrows and lobes, and a narrower (sag.) median glabellar area; however, a more detailed comparison between two species is difficult, because of the insufficiently adequate preservation of the illustrated specimens from Pamir. In both the publications cited above, a weakly arched preglabellar area was reported, while the available illustrations show incompletely preserved cranidia mainly illustrating the glabellar morphology. In the absence of data on the pygidial morphology, further comparison with the specimens from Pamir is difficult.

Order Asaphida Salter, 1864

Superfamily Asaphoidea Burmeister, 1843

Family Asaphidae Burmeister, 1843

Asaphidae gen. et sp. indet. (Text-figs 15B, C)

MATERIAL: NMW 2012.7G.100, pygidium plus thorax, NMW 2012.7G.101, pygidium.

REMARKS: These few asaphid pygidia, one with attached thoracic segments, are characterised by a slightly transverse semioval outline, a narrow axis gently tapering posteriorly and terminating near the pygidial margin combined with a wide doublure. The pygidium is effaced, but axial rings and up to 5 pleural ribs can be observed on the internal mould (Fig. $15 \mathrm{C})$. In the absence of data on cephalic and hypos- tome morphology generic determination of these specimens is impossible.

\section{Acknowledgements}

Leonid Popov and Christian Baars acknowledge support from the National Museum of Wales. Mansoureh Ghobadi Pour thanks the National Museum of Wales for logistical support on her visits to Cardiff; her work in Iran is supported by the Golestan University. The work of Lars Holmer was supported by Swedish Research Council (VR 2009-4395, 20121658 to LEH). We are grateful to Prof. Art Boucot (Oregon State University) and an anonymous reviewer, for comments on the manuscript.

\section{REFERENCES}

Alavi, M. 1991. Tectonic map of the Middle East: Tehran, Geological Survey of Iran, scale 1:5,000,000.

Andreeva, O.N. 1972. Brachiopods of the Ordovician Kuragan Formation of the South Urals. Paleontologicheskii Zhurnal, 1972 (1), 45-56. [In Russian]

Balashov, Z.G. 1968. Ordovician Endoceratoidea of the USSR, pp. 1-277. Izdatelstvo Leningradskogo Universiteta; Leningrad. [In Russian]

Balashova, E.A. 1966. Trilobites from the Ordovician and Silurian deposits of Pamir. Trudy Upravleniya Geologii Soveta Ministrov Tadzhikskoi SSR. Paleontologiya i Stratigraphiya, 2, 191-262. [In Russian]

Bassett, M.G., Popov, L.E. and Sokiran, E.V. 1999. Patterns of diversification in Ordovician cyrtomatodont rhynchonellate brachiopods. Acta Universitatis Carolinae, Geologica, 43, (1/2), 329-332.

Berberian, M. and King, G.C.P. 1981. Towards a paleogeography and tectonic evolution of Iran. Canadian Journal of Earth Science, 18, 210-265. DOI: 10.1139/e81-019

Berger, A.Ya. 1982. Ancient tentaculitides of Siberia. In Silurian of Siberian Platform, Sections, fauna and flora of the north-western part of the Tunguska Sineclise. Trudy Instituta Geologii i Geofiziki Sibirskogo Otdeleniya Akademii Nauk SSSR, 508, 132-141.

Billings, E. 1859. Description of a new genus of Brachiopoda and on the genus Cyrtodonta. Canadian Naturalist and Geologist, 4, 301-303.

Billings, E. 1862. New species of fossils from different parts of the lower, middle, and upper Silurian rocks of Canada. Palaeozoic Fossils, 1, 96-185.

Bogelopova, O.K., Kröger, B., Falahatgar, M. and Javidan, M. 2013. Middle Ordovician cephalopods from the Abarsaj area, northern Iran. In: Anders, L. and Mehlqvist, K. (Eds), Proceedings of the 3rd IGCP 591 Annual Meeting 
Lund, Sweden, 9-19 June 2013, Lund University, p. 50. Boucot, A.J., Johnson, J.G. and Staton, R.D. 1964. On some atrypoid, retzioid, and athyridoid Brachiopoda. Journal of Paleontology, 38, 805-822. URL:http://www.jstor.org/stable/1301600

Burmeister, H. 1843. Die Organisation der Trilobiten aus ihren lebenden Verwandten entwickelt; nebst einer systematischen Uebersicht aller zeither beschriebenen Arten, pp. 1-147. Ray Society; Berlin.

Chen, J. 1976. Advances in the Ordovician stratigraphy of North China with a brief description of nautiloid fossils. Acta Palaeontologica Sinica, 15, 55-74.

Chen, J. and Zou, X.1984. Ordovician cephalopods of the Ordos area, China. Memoir of the Nanjing Institute of Geology and Palaeontology, 20, 1-84.

Cocks, L.R.M. 1979. A silicified brachiopod fauna from the Silurian of Iran. Bulletin of the British Museum (Natural History), Geology, 32, 25-42.

Cocks, L.R.M. and Rong, J. 2000. Order Strophomenida. In: Kaesler, R.L. (Ed.), Treatise on Invertebrate Paleontology, Vol. H, Brachiopoda 2 (revised), pp. 216-348. Geological Society of America and Kansas University Press; Boulder, Colorado and Lawrence, Kansas.

Cocks, L.R.M. and Fortey, R.A. 1988. Lower Palaeozoic facies and faunas around Gondwana. In: Audley-Charles, M. G. and Hallam, A. (Eds), Gondwana and Tethys. Geological Society, London, Special Publication, 37, 183-200. DOI: 10.1144/GSL.SP.1988.037.01.10

Colmenar, J. and Álvaro, J.J. 2014. Integrated brachiopodbased bioevents and sequence-stratigraphic framework for a Late Ordovician subpolar platform, eastern Anti-Atlas, Morocco. Geological Magazine, DOI: http:// dx.doi.org/10.1017/S0016756814000533.

Cooper, G.A. 1956. Chazyan and related brachiopods. Smithsonian Miscellaneous Collections, 27, 1-1245.

Cuvier, G.L.C.F.D. 1797. Tableau élémentaire de l'histoire des animaux, pp. i-xvi + 1-710 14 pl. Deterville; Paris.

Dalman, J.W. 1828. Uppställning och Beskrifning af de i Sverige funne Terebratuliter. Kongliga Svenska Vetenskapsakademien Handlingar, 3 (for 1827), 85-155.

Davidson, T. 1882. A Monograph of the British Fossil Brachiopoda. Part 5 (1). Devonian and Silurian Supplements, pp. 1-134. Monograph of the Palaeontographical Society; London.

Destombes, J. 1972. Les trilobites de la sous ordre des Phacopina de l'Ordovicien del L'Anti Atlas (Maroc). Notes et Mémoires du Service Géologique de Maroc, 240, 1-113.

Dewitz, H.H. 1880. Ueber einige ostprussiche Silurcephalopoden. Zeitschrift der Deutschen geologischen Gesellschaft, 32, 371-393.

Dürkoop, A. 1970. Brachiopoden aus dem Silur, Devon und Karbon in Afghanistan. Palaeontographica, series A, 134, 153-225.
Evans, D.H. 1994. Siphonal and cameral deposits in Allumettoceras and the position of the Tripteroceratidae (Nautiloidea). Paläontlogische Zeitshrift, 68, 321-337. DOI: 0.1007/BF02991346

Evans, D.H., Ghobadi Pour, M. and Popov, L.E. 2013. Review of the Early to Mid Ordovician orthoconic cephalopods from Iran. Bulletin of Geosciences, 88, 21-44. DOI: 10.3140.bull. geosci.1355.

Flower, R.H. 1946. Ordovician cephalopods of the Cincinnati region. Bulletin of American Paleontology, 29, 1-656.

Flower, R.H. 1962. Notes on the Michelinoceratida. New Mexico Bureau of Mines and Mineral Resources, Memoir, 10, 21-55.

Flower, R.H. 1964a. The nautiloid order Ellesmeroceratida (Cephalopoda). New Mexico Bureau of Mines and Mineral Resources, Memoir, 12, 1-234.

Flower, R.H. 1964b. Nautiloid shell morphology. New Mexico Bureau of Mines and Mineral Resources, Memoir, 13, $1-78$.

Flower, R.H. and Kummel, B.1950. A classification of the Nautiloidea. Journal of Paleontology, 24, 604-616.

Foerste, A.F. 1926. Actinosiphonate, trochoceroid, and other cephalopods. Denison University Bulletin, Journal Science Laboratories, 1, 285-384.

Foord, A.H. 1887. On Endoceras duplex Wahl., with descriptions of three new species of Endoceras from the Ordovician of Sweden and Russia contained in the British Museum. Annals and Magazine of Natural History, Series 5, 20, 393-409.

Fortey, R.A. and Cocks, L.R.M. 2003. Palaeontological evidence bearing on global Ordovician-Silurian continental reconstructions. Earth-Science Reviews, 61, 245-307. DOI: 10.1016/S0012-8252(02)00115-0

Ghavidel-Syooki, M., Popov, L.E., Ghobadi Pour, M., Álvaro, J.J. and Ehsani, M.H. 2015a. Late Ordovician and early Silurian brachiopods from the Zagros Ranges, Iran. Earth and Environmental Science Transactions of the Royal Society of Edinburgh, 105, 159-187. DOI: http:// dx.doi.org/10.1017/S1755691015000079

Ghavidel-Syooki, M., Ghobadi Pour, M., Popov, L.E., Álvaro, J.J., Klishevich, I.A., Rakhmonov, U. and Ehsani, M.H. 2015b. Late Ordovician cephalopods, tentaculitides, machaeridians and echinoderms from Kuh-e Faraghan, High Zagros, Iran. Alcheringa, 39, \#\# [In press] DOI: 10.1080/03115518.2015.1052677

Ghobadi Pour, M. 2006. Early Ordovician (Tremadocian) trilobites from Simeh-Kuh, Eastern Alborz, Iran. In: M.G. Bassett and V.K. Deisler (Eds), Studies in Palaeozoic palaeontology. National Museum of Wales Geological Series, 25, 93-118.

Ghobadi Pour, M. and Popov, L.E. 2009. First report on the occurrence of Neseuretinus and Ovalocephalus in the Middle Ordovician of Iran. Acta Palaeontologica 
Polonica, 54, 125-133. DOI: 10.4202/app.2009.0113

Ghobadi Pour, M., Popov, L.E., Kebria-ee Zadeh, M.R. and Baars, C. 2011. Middle Ordovician (Darriwilian) brachiopods associated with the Neseuretus biofacies, eastern Alborz Mountains, Iran. Memoirs of the Association of Australasian Palaeontologists, 42, 263-283.

Hairapetian, V., Ghobadi Pour, M., Popov, L.E. and Modzalevskaya, T.L. 2012. Stegocornu and associated brachiopods from the Silurian (Llandovery) of Central Iran. Estonian Journal of Earth Sciences, 61, 82-104. DOI: 10.3176/earth.2012.2.02

Hairapetian, V., Ghobadi Pour, M., Popov, L.E., Hejazi, S.H., Holmer, L.E., Evans, D. and Sharafi, A. 2015. Ordovician of the Anarak Region: implications in understanding Early Palaeozoic history of Central Iran. Stratigraphy, 12, 22-30.

Hall, J. and Clarke, J.M. 1892-1895. An introduction to the study of the genera of Palaeozoic Brachiopoda. New York Geological Survey, Palaeontology, 8, (1), I-xvi+1-367, pl. 1-41; 8 (2), 318-394, pl. 21-84.

Harper, D.A.T., Mitchell, W.I., Owen, A.W. and Romano, M. 1985. Upper Ordovician brachiopods and trilobites from the Clashford House Formation, near Herbertstown, Co. Meath, Ireland. Bulletin of the British Museum (Natural History), Geology, 38, 287-308.

Hammann, W. and Leone, F. 1997. Trilobites of the postSardic (Upper Ordovician) sequence of southern Sardinia. Part 1. Beringeria, 20, 1-217.

Havlíček V. 1961. Rhynchonelloidea des böhmischenälteren Paläozoikums (Brachiopoda). Rozpravy Ústredního ústavu geologického, 27, 1-211.

Havlíček, V. 1971. Brachiopodes de l'Ordovicien du Maroc. Notes et Mémoires du Service Géologique du Maroc, 230, 1-135.

Havlíček, V. and Vanek, J. 1966. The biostratigraphy of the Ordovician of Bohemia. Sbornik Geologickych Ved, Paleontologie, 8, 7-68.

Hawle, I. and Corda, A.J.C. 1847. Prodrom einer monographie der Böhmischen Trilobiten. Abhandlungen der Bohmisch Gesellschaft Wissenschaft, 5, 117-292.

Holm, G. 1896. Om apikaläden hos Endoceras. Geologiska a Föreningens i Stockholm Förhandlingar, 18, 394-416.

Hupé, P. 1955. Classification des trilobites II. Annales de Paléontologie, 41, 91-304.

Hyatt, A. 1883-84. Genera of fossil cephalopods. Boston Society of Natural History, Proceedings, 22, p. 253-338. [253-272, December 1883; 273-338, January 1884.]

King, W. 1846. Remarks on certain genera belonging to the class Palliobranchiata. Annals and Magazine of Natural History, Series 1, 18, 26-42.

Kobayashi, T. 1927. Ordovician fossils from Corea and South Manchuria. Japanese Journal of Geology and Geography, $\mathbf{5}, 173-212$.
Kobayashi, T. 1931. Studies on the stratigraphy and palaeontology of the Cambro-Ordovician formation of Hua-lienchai and Niu-hsin-tai, south Manchuria. Japanese Journal of Geology and Geography, 8, 131-189.

Kobayashi, T. 1934. The Cambro-Ordovician formations and faunas of South Chosen. Palaeontology. Part I. Middle Ordovician faunas. Journal of the Faculty of Sciences, Imperial University of Tokyo, Section 2, 3, 329-519.

Kobayashi, T. 1935. Restudy of Manchuroceras with a brief note on the classification of Endoceroids. Journal of the Geological Society of Japan, 42, 436-452.

Kobayashi, T. 1937. Contributions to the study of the apical end of the Ordovician nautiloids. Japanese Journal of Geology and Geography, 14, 1-21.

Kolarova, F.N. 1925. The generic status of 'Triplecia' poloi. Bulletin of the Geological Society of China, 4, 215-219.

Kröger, B., Beresi, M.S. and Landing, E. 2007. Early orthoceratoid cephalopods from the Argentine Precordillera (Lower - Middle Ordovician). Journal of Paleontology, 81, 1263-1280. DOI: abs/10.1666/06-013.1

Kuhn, O. 1940. Palaozoologie in Tabellen, pp. 1-50. G. Fischer; Jena.

Kuhn, O. 1949. Lehrbuch der Paläozoologie, pp. i-v + 1-326. E. Schweizerbart; Stuttgart.

Lindenberg, H.G., Gröler, K., Jacobshagen, V. and Ibbeken, H. 1984. Post-Paleozoic stratigraphy, structure and orogenetic evolution of the southern Sabzevar zone and the Taknar block. Neues Jahrbuch für Geologie und Paläontologie, Abhhandlungen, 168, 287-326.

Ljashenko, G.P. 1955. New facts on the systematics of tentaculitids, nowakids and styliolinids. Bulleten Moskovskogo Obshchestva Ispytatelei Prirody, Otdelenie Geologichskoye, Novaia Seriya, 30, 94-95.

Malinky, J.M., Wilson, M.A., Holmer, L.E. and Lardeux, H. 2004. Chapter 22. Tube-shaped incertae sedis. In: Webby, B., Droser, M.L., Paris, F. and Percival, I. (Eds), The Great Ordovician Biodiversification Event. Columbia University Press, pp. 214-222.

Mansuy, H. 1908. Contribution à la Carte géologique de l'Indo-Chine: Paléontologie. Gouvèrnement Général de l'Indo-Chine, Direction Générale des Travaux Publics, Service des Mines, pp. 1-73. Imprimerie d'Extre^meOrien; Hanoi-Haiphong.

Martelli, A. 1901. Fossili del Siluriano Inferiore dellos Schensi (China). Societa Geologica Italiana Bollettino, 20, 295310.

McCoy F. 1844. A synopsis of the characters of the Carboniferous Limestone fossils of Ireland pp. 1-274. Dublin University Press; Dublin.

Milne Edwards, H. 1840. Histoire naturelle des Crustacés, comprenant l'anatomie, la physiologie et la classification de ces animaux, 3, pp. 1-638. Roret; Paris.

Neuman, R.B. 1968. Paleogeographic implications of Or- 
dovician shelly fossils in the Magog belt of the northern Appalachian region. In: Zen, A, White, W.S., Hadley, J.B. and Thompson, J.B., Jr. (Eds), Studies of Appalachian Geology: Northern and Maritime pp. 35-48. Interscience Publishers (a division of John Wiley and Sons).

Percival, I.G., Wright, A., Nicoll, R S. and M.A. Hamedi 2009. Martellia and associated Middle Ordovician brachiopods from the Katkoyeh Formation, east-central Iran. Memoirs of the Association of Australasian Palaeontologists, 37, 315-325.

Nikitina, O.I., Popov, L.E., Neuman, R.B., Bassett, M.G. and Holmer, L.E. 2006. Mid Ordovician (Darriwilian) brachiopods of South Kazakhstan. In: Bassett, M.G. and V.K. Deisler, (Eds), Studies in Palaeozoic palaeontology. National Museum of Wales Geological Series, 25, 145222.

Öpik, A. 1934. Über Klitamboniten. Tartu Universitatis (Dorpatensis), Acta and Commentationes, series A26, 4-239.

Pander, G.H. 1830. Beiträge zur Geognosie des Russichen Reiches, pp. 1-165. St. Petersburg,

Popov, L.E., Egerquist, E. and Zuykov, M.A. 2005. Ordovician (Arenig-Caradoc) Syntrophiidine brachiopods from the East Baltic region. Palaeontology, 48, 739-761. DOI: 10.1111/j.1475-4983.2005.00487.x

Popov, L.E., Bassett, M.G., Zhemchuzhnikov, V.G., Holmer, L.E. and Klishevich, I.A. 2009. Gondwanan faunal signatures from early Palaeozoic terranes of Kazakhstan and Central Asia: evidence and tectonic implications. In: Bassett, M.G. (Ed.) Early Palaeozoic Peri-Gondwanan Terranes: New Insights from Tectonics and Biogeography. The Geological Society, London, Special Publications, 325, 23-64. DOI:10.1144/SP325.3

Popov, L.E., Nikitin, I.F. and Sokiran, E.V. 1999. The earliest atrypides and athyridides (Brachiopoda) from the Ordovician of Kazakhstan. Palaeontology, 42, 625661. DOI: 10.1111/1475-4983.00089

Popov, L. E., Vinn, O. and Nikitina, O.I. 2001. Brachiopods of the redefined family Tritoechiidae from the Ordovician of Kazakhstan and South Urals. Geobios, 32, 131-155. DOI: 10.1016/S0016-6995(01)80057-7

Popov, L., Hairapetian, V., Ghobadi Pour, M., Buttler, C., Evans, D.H., Hejazi, S.H. and Jahangir, H. 2014. Llandovery fauna of Iran during the post-extinction recovery. The Third International Symposium of the International Geosciences Programme Project 589 (IGCP- 589): Development of the Asian Tethyan Realm: genesis, process and outcomes. Tehran, 19-26 October, 2014, Abstract volume and proceedings, 105-110.

Ramezani, J. and Tucker, R.D. 2003. The Saghand region, central Iran: $\mathrm{U}-\mathrm{Pb}$ geochronology, petrogenesis and implications for Gondwana tectonics. American Journal of Science, 303, 622-665. DOI: 10.2475/ajs.303.7.622

Rong, J. and Cocks, L.R.M. 1994. True Strophomena and a re- vision of the classification of strophomenind and 'stropheodontid' brachiopods. Palaeontology, 37, 651-694.

Rong, J., Harper, D.A.T., Zhan, R., Huang, Y. and Cheng, J. 2005. Silicified rhynchonelliform brachiopods from the Kuniutan Formation (Darriwilian: Middle Ordovician), Guiyang, South China. Palaeontology, 48, 1211-1240. DOI: 10.1111/j.1475-4983.2005.00506.x

Ross, R.J. 1972. Fossils from the Ordovician bioherm at Meiklejohn Peak, Nevada. United States Geological Survey, Professional Paper, 685, 1-47.

Reed, F.R.C. 1906. The Lower Palaeozoic fossils of the northern Shan States, Burma. Memoirs of the Geological Survey of India, Palaeontologia Indica, New Series, 2, 1-154.

Rozman, Kh.S. 1969. Late Ordovician brachiopods of the Siberian Platform. Paleontologicheskii Zhurnal, 1969 (3), 86-108.

Rubel, M. 1961. Lower Ordovician brachiopods of the superfamilies Orthacea, Dalmanellacea, and Syntrophiacea of East Baltic. Eesti NSV Teaduste Akadeemia Geoloogia Instituudi, Uurimuse, 6, 141-226.

Ruttner, A., Nabavi, M. and Hajian, J. 1968. Geology of the Shirgesht area (Tabas area, East Iran). Reports of the Geological Survey of Iran, 4, 1-133.

Salter, J.W. 1864. A monograph of the British trilobites from the Cambrian, Silurian and Devonian formations. Part 1. Monograph of the Palaeontographical Society, 16, 1-80.

Schallreuter, R., Hinz-Schallreuter, I., Balini, M. and Ferretti, A. 2006. Late Ordovician Ostracoda from Iran and their significance for palaeogeographical reconstructions. Zeitschrift für Geologische Wissenschaften, 34, 293-345.

Schmidt, H. 1965. Neue Befunde an Paläozoischen Rhynchonellacea (Brachiopoda). Senckenbergiana Lethaea, 46, 1-25.

Schuchert, C. 1893. A classification of the Brachiopoda. American Geologist, 11, 141-167.

Schuchert, C. 1913. Class 2. Brachiopoda In: von Zittel, K.A. (Ed.), Text-book of Palaeontology, 1, (2nd ed.), pp. 355420. MacMillan; London.

Schuchert, C. and Cooper, G.A. 1931. Synopsis of the brachiopod genera of the suborders Orthoidea and Pentameroidea, with notes on the Telotremata. American Journal of Science, 22, 241-251.

Schuchert, C. and Cooper, G.A. 1932. Brachiopod genera of the suborders Orthoidea and Pentameroidea. Memoirs of the Peabody Museum of Natural History, 4, 1-270.

Sharkovski, M., Susov, M. and Krivyakin, B. (Eds) 1984. Geology of the Anarak area (Central Iran), Explanatory text of the Anarak quadrangle map, 1:250.000, V/O Technoexport Report, 19, pp. 1-143. Gological Survey of Iran; Tehran.

Sheehan, P.M. 1977. Late Ordovician and earliest Silurian meristellid brachiopods in Scandinavia. Journal of Paleontology, 51, 23-43. 
Sweet, W.C. 1964. Orthocerida. In: Moore R.C. (Ed.), Treatise on invertebrate paleontology. Part K. Mollusca 3, Cephalopoda. General features, Endoceratoidea, Actinoceratoidea, Nautiloidea, Bactritoidea, pp. 216-261. Geological Society of America and University of Kansas Press; Boulder, Colorado and Lawrence, Kansas.

Teichert, C. 1933. Der bau der actinoceroiden cephalopoden. Palaeontographica, Abt. A., 78, 111-230.

Teichert, C. 1964. Endocerida. In: Moore, R.C. (Ed.), Treatise on invertebrate paleontology. Part K. Mollusca 3, Cephalopoda. General features, Endoceratoidea, Actinoceratoidea, Nautiloidea, Bactritoidea, pp. 160-189. Geological Society of America and University of Kansas Press; Boulder, Colorado and Lawrence, Kansas.

Ulrich, E.O. and Cooper, G.A. 1936. New genera and species of Ozarkian and Canadian brachiopods. Journal of Paleontology, 10, 616-631.

Ulrich, E.O. and Cooper, G.A. 1942. New genera of Ordovician brachiopods. Journal of Paleontology, 16, 620-626.

Villas, E. 1985. Braquiópodos del Ordovícico medio y superior de las Cadenas Ibéricas Orientales. Memorias del Museo Paleontológico de la Universidad de Zaragoza, 1, 1-223.

Waagen, W. 1883. Salt-Range fossils, vol. I, Part 4, Productus Limestone fossils, Brachiopoda. Memoirs of the geological Survey of India, Palaeontologia Indica (series 13), 2, 391-546.

Wahlenberg, G. 1821. Petrificata Telluris Svecanae. Nova Acta Regiae Societatis Scientiarum Upsaliensis, 8, 1116.

Weber, V.N. 1948. Silurian trilobites of the USSR. 1: Lower Silurian trilobites. Monografiya po paleontologii SSSR, 69, (1), 1-113. [In Russian with English summary]

Williams, A. 1951. Llandovery brachiopods from Wales with special reference to the Llandovery District. Quarterly Journal of Geological Society, London, 107, 85-136.

Williams, A. 1962. The Barr and Lower Ardmillan Series (Caradoc) of the Girvan District, south-west Ayrshire, with descriptions of the Brachiopoda. Memoir of the Geological Society of London, 3, 1-267.

Williams, A. 1963. The Caradocian brachiopod faunas of the Bala District, Merionethshire. Bulletin of the British Museum (Natural History), Geology, 8, 329-471.

Williams, A. and Curry, G.B. 1985. Lower Ordovician Brachiopoda from the Tourmakeady Limestone, County Mayo, Ireland. Bulletin of the British Museum (Natural History), Geology, 38, 183-269.

Wirth, E. 1936. Über "Clitambonites" giraldii Martelli und Yangtzeella poloi Martelli aus dem Ordoviz Chinas. Paläontologische Zeitschrift, 18, 292-302.

Woodward, S.P. 1852. A manual of the Mollusca; or rudimentary treatise of recent and fossil shells, pp. i-Xvi+1486. London.

Yoh, S.S. 1945. On the inner structure of a new species of Yangtzeella. Bulletin of the Geological Society of China, 24, 11-14.

Yun, C.S. 2011. Ordovician cephalopods from the Jigunsan Formation, Taebaek-Yeongwol, Korea. Journal of the Paleontological Society of Korea, 27, 149-259.

Zhan, R. and Jin, J. 2005a. Brachiopods from the Dashaba Formation (Middle Ordovician) of Sichuan Province, Southwest China. Special Papers in Palaeontology, 74, 1-63.

Zhan, R. and Jin, J. 2005b. Brachiopods from the Middle Ordovician Shihtzupu Formation of Yunnan Province, China. Acta Palaeontologica Polonica, 50, 365-393.

Zhan, R., Jin, J. and Li, G. 2007. The Saucrorthis fauna (Brachiopoda) and its implication for the Ordovician radiation in South China. Acta Palaeontologica Sinica, 46, 515-522.

Zhan, R., Jin, J. and Chen, P. 2010. Early-Mid Ordovician Yangtzeella (Syntrophiidina, Brachiopoda) and its evolutionary significance. Palaeontology, 53, 77-96. DOI: 10.1111/j.1475-4983.2009.00921.x

Zhan, R., Luan, X., Huang, B., Liang, Y., Wang, G. and Wang, Y. 2014. Darriwilian Saucrorthis Fauna: implications for the Great Ordovician Biodiversification Event (GOBE). Estonian Journal of Earth Sciences, 63, 23-328. 